\title{
Reallocating children's time: coping strategies after the 2010 Haiti earthquake
}

\author{
Rafael Novella ${ }^{1}$ and Claire Zanuso $2,3^{*}$
}

*Correspondence: zanusoc@afd fr

${ }^{2}$ Agence Française de

Développement (AFD), 5 rue

Roland Barthes, 75012 Paris, France

Full list of author information is

available at the end of the article

\begin{abstract}
This paper estimates the impact of the 2010 Haiti earthquake on the household decision about children's time allocation. Using original data and objective geological measures, we exploit the fact that the earthquake might affect the decision about children's time through its magnitude and household's revealed vulnerability. Separated measures of the earthquake magnitude and its damage allow us to estimate the impact of the household's vulnerability on the decision about the time allocation of children 10 to 17 years old. We are also able to analyze the differentiated effect on market and domestic work. Our results show that vulnerability at the time of the earthquake severely affects investments in children's human capital almost 3 years after the shock, which increases the household's risk of staying in poverty.
\end{abstract}

JEL Classification: J13, J22, O54, P46, Q54

Keywords: Child labor, School attendance, Natural disasters, Haiti

\section{Introduction}

Frequency and intensity of natural and environmental disasters are on the rise worldwide. Latin America and the Caribbean (LAC) is one of the more disaster-prone areas of the world (Heger et al. 2008; Rasmussen) and suffers the lowest level of insurance coverage (Grislain-Letrémy 2013; Borensztein et al. 2009). For instance, the financial cost of natural disasters in the region has risen from US $\$ 16$ billion, in the period between 1985 and 1999, to more than US\$26 billion, in the period between 2000 and 2014 (EM-DAT 2015). Although the increasing number of studies investigates both the causes and effects of natural disasters, little is still known about the household's capacity to protect its human capital investment when confronted by such shocks.

The primary objective of this paper is to analyze the medium-term (about 3 years after) impact of the 2010 Haiti earthquake on households' decision about children's time allocation. We argue that reallocating children's time is a household coping strategy against an extreme adverse shock, which could lead to persistent negative effects on human capital (Jacoby and Skoufias 1997). The full impact of natural disasters is not entirely natural. They are triggered by external hazards but also stem from vulnerability. Vulnerability is a multidimensional and dynamic phenomenon, which definition varies among disciplines and research areas. ${ }^{1}$ For instance, the disaster risk literature defines vulnerability as "the capacity to be harmed" (Field 2012) or as in Dayton-Johnson J (2004) "vulnerability is the expected value of the damage that would occur conditional on the realization of the

(c) The Author(s). 2018 Open Access This article is distributed under the terms of the Creative Commons Attribution 4.0 International License (http://creativecommons.org/licenses/by/4.0/), which permits unrestricted use, distribution, and reproduction in any medium, provided you give appropriate credit to the original author(s) and the source, provide a link to the Creative Commons license, and indicate if changes were made. 
shock." In practical terms, however, the different elements in which one should focus the study of expected vulnerability (i.e., injury, loss, disruption of livelihood) are subject to constant change, and hence, it is very difficult to estimate them. Therefore, for practical reasons related to data availability, we take into account damage known to have occurred in the past; in other words, we do not rely on the "expected value" or the risk of damage but on the "revealed vulnerability" (Birkmann 2013).

Even before the 2010 earthquake, Haiti was the poorest country in LAC and among the poorest worldwide ${ }^{2}$ and had one of the poorest education systems in the world (e.g., about $60 \%$ of Haitians have no more than primary school education). Moreover, since 1900, Haiti has been exposed to more natural disasters than any other country in the Caribbean (Briguglio 1995; Heger et al. 2008). On 12 January 2010, Haiti was hit by an unanticipated magnitude 7.0 earthquake, classified as one of the four greatest killers recorded worldwide since 1990 and a massive destroyer of public and private infrastructure. The earthquake smacked headlong into the metropolitan area of Port-au-Prince, home to over one in five Haitians, and also households far beyond the capital. Despite the immediate response from the international community, with rescue teams and pledges of financial assistance and support for reconstruction and development, recovery in the country is still in process nowadays. Evidence shows that assistance was not particularly targeted to the most affected or vulnerable (Échevin 2011) and that instead it largely overlooked the population outside the conurbation of Port-au-Prince, even though just over six in ten of the households hit were outside the capital. Three years after the earthquake, just over one third of the population barely managed to make ends meet (Herrera et al. 2014). Moreover, in 2012, almost 30\% of 10-17-year-old children are not in school or dedicate only few hours to studying because they need to contribute to household income or work in the household (Zanuso et al. 2014).

This paper uses original information collected during an extended fieldwork aimed at designing, coordinating, and implementing the first nationwide survey about living conditions and labor market after the 2010 earthquake. The Post Earthquake Living Conditions Survey (ECVMAS) consists of 4951 households, in 500 primary sampling units (PSUs), interviewed in the second half of 2012 and is representative of the entire population of the country (Herrera et al. 2014). ${ }^{3}$ Additionally, we merge, at the PSU level, households and individuals in ECVMAS with the measures of the strength of ground motion made available by the US Geological Survey (USGS). The combined data allow us to distinguish between the natural hazard occurrence, which is the observed physical intensity of the 2010 earthquake, and the natural disaster impact (measured by a damage score of the dwelling), which involve the interaction of the natural hazard and vulnerability. Two additional features of the data make it suitable for the purpose of our paper. First, it includes children's self-reported information about the allocation of their own time. Given the social stigma associated with child labor and absence from school, parents might tend to underreport them. Therefore, it is expected that asking children directly would reduce this source of measurement error. Second, in contrast to most of the literature on the topic (Edmonds 2007), our data allows us to disentangle the effect on the decision about market and domestic work. Our final sample consists of 3833 children aged between 10 and 17 years, who in 2012 are still living in the same house or community where they lived at the time of the earthquake and who belong to the same household to which they belonged at the time of the earthquake. ${ }^{4}$ 
Analyzing the impact of the earthquake on children's time allocation is not straightforward. First, the direct effect of the natural hazard on households is manifested in their revealed vulnerability, which, in turn, might affect the decision about children's time use. Second, the earthquake might affect the households' decision through several other channels, for instance, the damage or destruction of services' infrastructure (e.g., roads, schools) and staff (e.g., reduction in the number of teachers); changes in the household's composition (e.g., degree of closeness between the child and the adult decision-maker in the household) and economic circumstances; changes in labor markets, which for instance might affect the opportunity cost of sending children to school; international aid response; and changes in children's physical and mental health, which for instance might affect school readiness.

To identify the effect of the household's socioeconomic vulnerability at the time of the earthquake on the current decision of children's time allocation, we use several empirical specifications accounting for the effect of the earthquake on children's time allocation through these channels. Including a large set of household's, child's, and community's characteristic at the time of the 2010 earthquake attempts to wash away unobserved components that might affect the household's vulnerability and decision about children's time use. Moreover, we account for the potential correlation between the error terms of the equations for the different alternatives for children's time use. ${ }^{5}$ Our dependent variables correspond to the household decision, in 2012, about participation of children into different activities (idle, school only, work only, school and work) and the number of hours studying and in market and domestic work. For our main variable of interest, the household's vulnerability, we empirically define it as the regression residual of the total destructive effect of the earthquake on its physical impact (i.e., peak ground acceleration) and a household's asset index in 2010. Finally, the other covariates consist in retrospective questions corresponding to the period just before the 2010 earthquake collected in the 2012 ECVMAS survey. The data quality literature stresses that when a phenomenon of large magnitude happens, the risk of measurement error associated to recall is reduced (De Nicola and Giné X 2014; Dex 1995). According to Brown and Kulik (1977)'s "flashbulb" memories theory, a highly surprising and consequential event, like the 2010 earthquake, rises memories that show little forgetting (Winograd and Neisser 2006). ${ }^{6}$ Moreover, we account for the potential correlation between the error terms of both the set of equations related to participation into different activities (i.e., idle, school only, work only, school and work) and the set of hours into each category (i.e., leisure, study, market and domestic work). Finally, we also account for unobservable characteristics at the community level, such as social norms about child labor, services supply, local labor market conditions, and aid received as consequence of the earthquake.

Results from both extensive and intensive margins show that the household's vulnerability is negatively associated with medium-term investments in children's human capital. It is associated with an increase in the risk of sending children to work rather than schools, in the number of hours of domestic and market work, and with a reduction in the number of hours of study. These results highlight the importance of separating market and domestic work activities to correctly assess child labor. Moreover, we find evidence of different time allocations according to children's characteristics. For instance, while age increases hours of domestic work for girls work more than for boys, it increases hours of market work for them more than for girls. In addition, the further away a child is biologically from 
the household head is associated to lower investments in children's human capital. Being active in the labor market at the time of the earthquake is found to be very important to increase the probability of working and reducing the probability of attending school in 2012. Also, exposure to a larger number of negative economic shocks between 2010 and 2012 is associated to lower investments in children's human capital.

This paper contributes to two strands of literature. First, it contributes to the literature looking at the effect of natural disasters on economic well-being and households' coping strategies. Our results suggest that more vulnerable households can resort to coping strategies leading to persistent negative effects on human capital, such as taking children out of schools, reducing the time for studying, or increasing their work participation (Baez et al. 2010; De Janvry et al. 2006). Second, this paper contributes to child labor literature as it brings more evidence on the differentiated impact on market and domestic work.

The paper is organized in seven sections. Section 2 reviews the relevant literature on the effects of natural disasters on human capital and child labor and presents the general framework used to evaluate the situation for children in Haiti. Section 3 provides background information on the earthquake and the socioeconomic context in which it took place. Section 4 describes the data used in the analysis and provides a discussion of intensity, vulnerability, and damage measures. Section 5 presents the empirical strategies to identify the mentioned effects. This is followed by a presentation of the results in Section 6. Finally, Section 7 concludes the paper and discusses policy options.

\section{Previous findings and conceptual framework}

The questions we address in this paper are at the conjunction of two fields of research: the impact of natural disasters and child labor studies. In both cases, the literature barely cover the specific case of Haiti.

In part due to climate change, there has been a recently substantial growth in interest in the impact of natural disasters. This trend is set to grow due to a worrying rise in the impact of natural disasters on economic welfare over the last decade. Research focusing more specifically on countries' resilience suggests that these disasters have devastating effects on economic growth in developing countries because they prevent physical and human capital accumulation, although the channels behind this phenomenon remain unclear (Skoufias 2003). Most of the existing studies on the economic impact of natural disasters have been driven by the availability of the international Emergency Disasters Database (EM-DAT), which contains information about disasters and their damage worldwide since 1900. Macroeconomics studies have put particular attention on the human and economic costs of these disasters. As expected, these studies conclude that even though developing countries are not more exposed than developed countries to natural hazards (i.e., physical and environmental factors), they are more vulnerable to disasters. The channels through which the disasters produce such different impacts remain as a "black box" in these studies even though some suggest differences in institutional factors (e.g., governance, inequalities) (Cavallo and Noy 2009; Noy 2009; Kahn 2005).

To the best of our knowledge, the only existing study evaluating the 2010 earthquake's impact in Haiti adopts an indirect and macroeconomic approach (Cavallo et al. 2010). It sets out primarily to put a figure to the total financial impact of the earthquake. The estimates are based on strong assumptions and are not very reliable, as the authors themselves recognize. Herrera et al. (2014) and Zanuso et al. (2014) (more specifically focused 
on youth) based on ECVMAS 2012 data, present the most up-to-date image of the labor market situation in Haiti and a systematic and comparative analysis with the EEEI 2007 data is conducted. They calculate comparable indicators and describe the evolution of the labor market in a 5-year interval (before and after the earthquake), but they highlight that the observed dynamic cannot be attributed to the earthquake only, as so many largescale events have intervened in the meantime (floods, hurricanes, epidemics, etc.). More recently, Saint-Macary and Zanuso (2015) assess the long-lasting effects of the 2010 Haiti earthquake on household well-being.

\subsection{Effects of natural disasters on education and child labor}

Modeling the impacts of natural disasters on human capital in a comprehensive manner is not straightforward. The literature have developed theoretical frameworks to model different pieces of the causal chain linking different shocks-including natural disastersto proxy determinants of human capital and other dimensions of human welfare, but there is no consensus of whether natural disasters have consequences on the creation and use of human capital (Baez et al. 2010). The existing economic literature strongly suggests that the households' capacity in poor countries to smooth consumption across time and states of nature is limited. This seems to be especially true in the case of large generalized shocks such as natural disasters, when some of the informal mechanisms of risk-sharing become less widespread (Jacoby and Skoufias 1997; Beegle et al. 2002). This section does not aim to review the whole existing findings at the household level on the impacts of natural disasters on human capital, and we cite only those studies which are directly related to the impact on education and child labor. ${ }^{7}$

The theoretical impact of natural disasters on schooling is ambiguous due the varying and sometimes contradicting effects involved. On the one hand, the damages or destruction of schools and complementary infrastructures and resources (e.g., roads and teachers) can worsen the whole education system. Additionally, if natural shocks worsen, the economic situation of households and the access to credit, insurance, or other coping mechanisms are limited; dropping children out of school may be the last resort to reduce outgoings (Jensen 2000; Jacoby and Skoufias 1997) or to increase household income by putting them to work or increasing their participation to domestic work activities (Basu and Van 1999; Edmonds 2007). Huisman and Smits (2009) argue this is specially the case in countries where laws regarding compulsory education are not strictly enforced, such as in Haiti. On the other hand, if a natural disaster changes the opportunity cost of sending children to school, through a reduction in market wages for example, or if international assistance increase the supply of education services (Adelman and Holland 2015), the direction of the overall effect remains unclear (Baez et al. 2010).

Empirically, it is complex to disentangle all these mechanisms. To the best of our knowledge, only one research tries to assess the effects of a large earthquake on child labor. ${ }^{8}$ Santos (2007) finds that children in households most affected by the 2001 earthquake in El Salvador were three times more likely to work after the shock. The intensive margin results show an increase of their labor supply of about $32 \mathrm{~h}$ per week relative to children in control areas. Studies assessing the effects of other types of disasters (e.g., droughts, floods, rainfall shocks, hurricanes) find that these shocks are associated with declines in enrollment rates or delays in school enrollment (Alderman et al. 2006; Jensen 2000; Jacoby and Skoufias 1997). Many studies show that natural disasters are strongly correlated with 
an increase of workforce, including children, and more hours devoted to off-farm activities at the expense of lower wages (Jalan and Ravallion 1999; Beegle et al. 2003; De Janvry et al. 2006; Santos 2007; Baez and Santos 2007). Baez and Santos (2007) estimate that as a consequence of Hurricane Mitch in Nicaragua, child labor force participation increases in 8.5 percentage points (p.p.) and the proportion of children both enrolled in school and working more than doubled. Most of case studies evidence that the impact can be largely negative, and some of them show the potential detrimental effects can be long-lasting (Alderman et al. 2006). Others studies on human capital and shocks (not only natural disasters) further stress that educational achievement is highly path-dependent (Bustelo et al. 2012; Strauss and Thomas 2007).

\subsection{Children's time allocation in developing countries}

Literature about children's time allocation in developing countries point to a number of determinants of the demand for education and the supply of child labor. A detailed overview of recent developments of this literature can be found in Edmonds (2007), and a review with a more theoretical focus in Basu and Van (1999). As Basu and Van (1998) mention, the allocation of children's time to non-labor activities (education or leisure) represents a luxury good for poor households, which can be consumed only once their income rises beyond a certain threshold. Sending children to work, in contrast to sending them to schools, carries negative consequences both for the children's future well-being and, through the positive externalities of education on growth, for the growth of the society as a whole (Basu and Van 1999).

Theoretical and empirical studies on the main determinants of the household's decision to send children to work rather than to school can be grouped into two main veins: the demand for education, introduced by Becker (1964), and the one that focuses on the impact of various constraints affecting the supply of child labor, the demand for education, or both simultaneously. According to Becker (1964)'s theory, whether to send their children to school is the result of a trade-off between the expected returns and the cost of education (e.g., tuition, material, compulsory uniform, transport, and opportunity cost). It predicts that children may work because the net returns relative to alternative uses of time such as school attendance are low (compared with its cost) and the returns to work experience are relatively larger. The second vein highlights the effect of various constraints on the allocation of children's time between school and work (Bhalotra 2007; Grimm 2011). Imperfections in the markets for labor and land (Bhalotra and Heady 2003), poverty (Jensen and Nielsen 1997; Basu and Van 1998), and credit market imperfections (Jacoby and Skoufias 1997; Ranjan 2001; Cigno and Rosati 2006) are the main set of constraints explaining the emergence of child labor and the concomitant fall-off in school attendance (Dammert 2010; De Vreyer et al. 2013; Senne 2014). All these constraints, in addition to the degree of altruism of the decision-taker in the household (Baland and Robinson 2000), drive the final decision about the child's time allocation. This framework suggests how an external negative shock might affect the households' decision in developing countries. In fact, even where incentives favor education over work, a household may be obliged by budget constraint to send a child to work. When poverty constraints are binding, the opportunity cost of studying is too high and parents are due to send children to work rather than to school. Moreover, when capital markets are imperfect, this model predicts that even altruistic parents may sacrifice investments in children's education. 
The existing empirical research about child labor tend to focus on the effects of factors, either the characteristics of parents and their households (Basu et al. 2010; Buchmann 2000; Patrinos and Psacharopoulos 1997) or country level (Fan 2004; Levy 1985). This is problematic, since we know that the decisions of parents regarding work and schooling of their children are influenced by factors at the household level as well as by characteristics of the context in which the household is living (e.g., the local labor market and the available educational facility characteristics) (Huisman and Smits 2009). Webbink et al. (2013) develop a new framework including simultaneously three categories of child labor determinants: resources (Basu and Van 1998; Ranjan 2001), family factors (or structural factors) (Edmonds 2006), and cultural explanations (Delap 2001). We aimed at adding vulnerability as an additional dimension.

In our ex-post vulnerability assessment, our measure of vulnerability is not an expected degree of loss but is based on the observed (revealed) level of damage on dwellings.

\section{Context}

\subsection{Haitian context}

Haiti is the poorest country in the Western Hemisphere and ranks 161 among 186 countries in the Human Development Index of the United Nations Development Programme. Three years after the 2010 earthquake, poverty is still high, and particularly in rural areas, just over one third of the population barely managed to make ends meet (Herrera et al. 2014). According to the new national poverty line produced by the government of Haiti and based on the ECVMAS 2012, more than one in two Haitians was poor, living on less than $\$ 2.41$, and one person in four was living below the national extreme poverty line of $\$ 1.23$ a day. A comparison of household earnings (with the level of income deemed by households to be the minimum required to live) shows that nearly eight in ten households can be classified as "subjective poor" (Herrera et al. 2014). With a population of 10.4 million people, ${ }^{9}$ Haiti is also one of the most densely populated countries in Latin America. Half of the population is under 21 years old, and nearly $60 \%$ of Haitians have no more than primary school education. In 2012, almost $30 \%$ of $10-17$-year-old children were not in school or dedicate only few hours to studying because they need to contribute to household income, work in the household, or do nothing (Zanuso et al. 2014).

Prior to the earthquake, the country had already one of the poorest education systems in the world. Right after its independence (in 1804), the importance of education was recognized and the first Constitution, promulgated in 1805, noted explicitly that "education shall be free. Primary education shall be compulsory. State education shall be free at every level." These principles were never put into practice. The education offered to Haitian children was, and still is, inadequate in terms of quality, quantity, and accessibility (Lunde 2010). Both the direct costs of attending school (e.g., tuition and other fees, mandatory uniforms, transport, books) and the opportunity costs, particularly in the form of lost labor for the household, remain barriers to achieving universal primary enrollment and completion. The private education system has grown by default and continuously, from 20\% in the 1959-1960 to 75\% in 1995-1996 (Salmi 2000). In 1997, the Ministry of National Education, Youth and Sport (MENJS) set out a National Education and Training Plan (PNEF) to reform the education system in Haiti. The reformed Haitian education system is used as reference here, even if some parts of the country, especially in rural areas, the traditional educational system still operates (Lunde 2010). In the reformed 
system, education comprises three core levels: (i) pre-school for 3 to 5 years old, not compulsory; (ii) primary education for 6 to 14 years old; and (iii) secondary education for 15 to 18 years old (see Table 7 in the Appendix). The legal age for admission to school is 6 years, and in the reformed system, children who go through normal progression complete primary at the age of 14. In fact, the last school census before the earthquake (2002-2003) highlighted that the average age of students in grade 6, for instance, was 16 years old, when the corresponding age for that grade should be 11 or 12 years old (Adelman and Holland 2015).

Even though the earthquake strongly affected the supply of education services, the number of schools were still larger in 2011-2012 than in 2002-2003. In 2002, Haiti counted with a total of 15,268 schools, of which $92 \%$ were nonpublic, accounting for more than $80 \%$ of enrolled students. The 2011-2012 census, conducted less than 2 years after the 2010 earthquake, counted 16,072 schools across the country in total, of which more than $88 \%$ were private institutions. This persistently large share of nonpublic education provision makes difficult the assurance of education quality in Haiti as nonpublic schools are very heterogeneous and they largely ignore government regulations and accreditation standards (Lunde 2010). In 2012, according to the ECVMAS survey, private education represents about $65 \%$ of primary and secondary school enrollment, one of the highest proportion of private school enrollment in the world.

In addition, between 2002 and 2011, total social expenditure, including education, in the country was reduced from 2.7 to $1.5 \%$ of GDP. Lamaute-Brisson (2013) reveals that the evolution of government education expenditure was erratic between 2002 (1.65\% of GDP) and 2005 and then it collapsed in 2006 (0.57\% of GDP) until 2011 (0.59\% of GDP), when it picked up. This volatility is explained by the fragile political situation and the volatility of GDP growth itself.

\subsection{The 2010 earthquake}

The magnitude 7.0 earthquake that hit Haiti on 12 January 2010 was one of the four greatest killers recorded worldwide since 1990. Official figures place it as being twice as lethal as any previous earthquake of the same magnitude (Bilham 2010). Although recent surveys by international institutions suggest that the official death count is overestimated (Lundahl 2013; Schuller and Morales P 2012), there is no question about the severity of its repercussions (Kolbe et al. 2010; Schwartz et al. 2011; Doocy et al. 2013). The death toll as recorded in EM-DAT (2015) is estimated at 222,600. Haiti is one of the most vulnerable developing countries when it comes to natural disasters and the most exposed country in the region (Heger et al. 2008; Briguglio 1995). It has been hit by just over 50 natural disasters since 1900. Another aspect, which might explain why Haiti is even more vulnerable than its neighbors Dominican Republic and Jamaica is the level of development and incomplete insurance markets that increase the impact of the shocks when they occur (Strobl 2012). The earthquake's repercussions were much more dramatic here than in other countries hit by stronger earthquakes. The context surrounding the earthquake was particularly ill-fated in that Haiti had been victim to either a tropical storm or severe flooding every year of that entire decade. The international EM-DAT database shows that these disasters prior to the earthquake affected over one million people in total and were responsible for nearly 7,000 deaths (EM-DAT 2015). Other countries have been struck by similar or stronger earthquakes, but the repercussions were much more dramatic for Haiti 
(Cavallo et al. 2010). For instance, an earthquake with a magnitude of 7.1 hit Christchurch, New Zealand's second-largest city, in 2010 with no fatalities. Similarly, an 8.8 earthquake hit central Chile that same year causing 525 deaths. The same holds true for extreme weather events such as hurricane Ike (2008), which battered Cuba and Haiti causing seven fatalities in Cuba, but more than 100 times that number in Haiti (793 deaths) (Fig. 1).

The 2010 earthquake was largely unanticipated and smacked headlong into the metropolitan area of Port-au-Prince, home to over one in five Haitians, destroying public buildings and housing as it went. It constitutes a unique natural experiment setting for the study of households' responses to this sort of shocks.

Material and human damage was huge in the area hit by the earthquake, but did not affect all the households in the same way. In Haiti, three times more makeshift dwellings than permanent buildings were destroyed in the hardest hit areas. Moreover, makeshift housing in the least-affected areas suffered greater damage than permanent buildings in the hardest hit areas (Herrera et al. 2014). The earthquake may well be a natural phenomenon, but its differentiated effect was also the result of massive social inequalities and vulnerabilities that magnified its effects among the most disadvantaged.

Despite the immediate response from the international community, with rescue teams and pledges of financial assistance and support for reconstruction and development, things are still far from being ideal. Six months after the earthquake, Échevin (2011) finds that the location of households emerges as the main criterion to explain the assistance allocation; the programs were not specifically targeted at people who need it the most, because of their low level of subsistence or losses due to the earthquake. Using ECVMAS, Herrera et al. (2014) corroborate these results. Institutional assistance largely overlooked the population outside the conurbation of Port-au-Prince, even though just over six in ten of the households hit were outside the capital. In fact, more earthquake victims were not living in camps than in them, in which a large proportion of the aid was concentrated. Most of the households had ceased receiving aid even though their situation had not improved. A full $80 \%$ of the population reported that aid had stopped more than

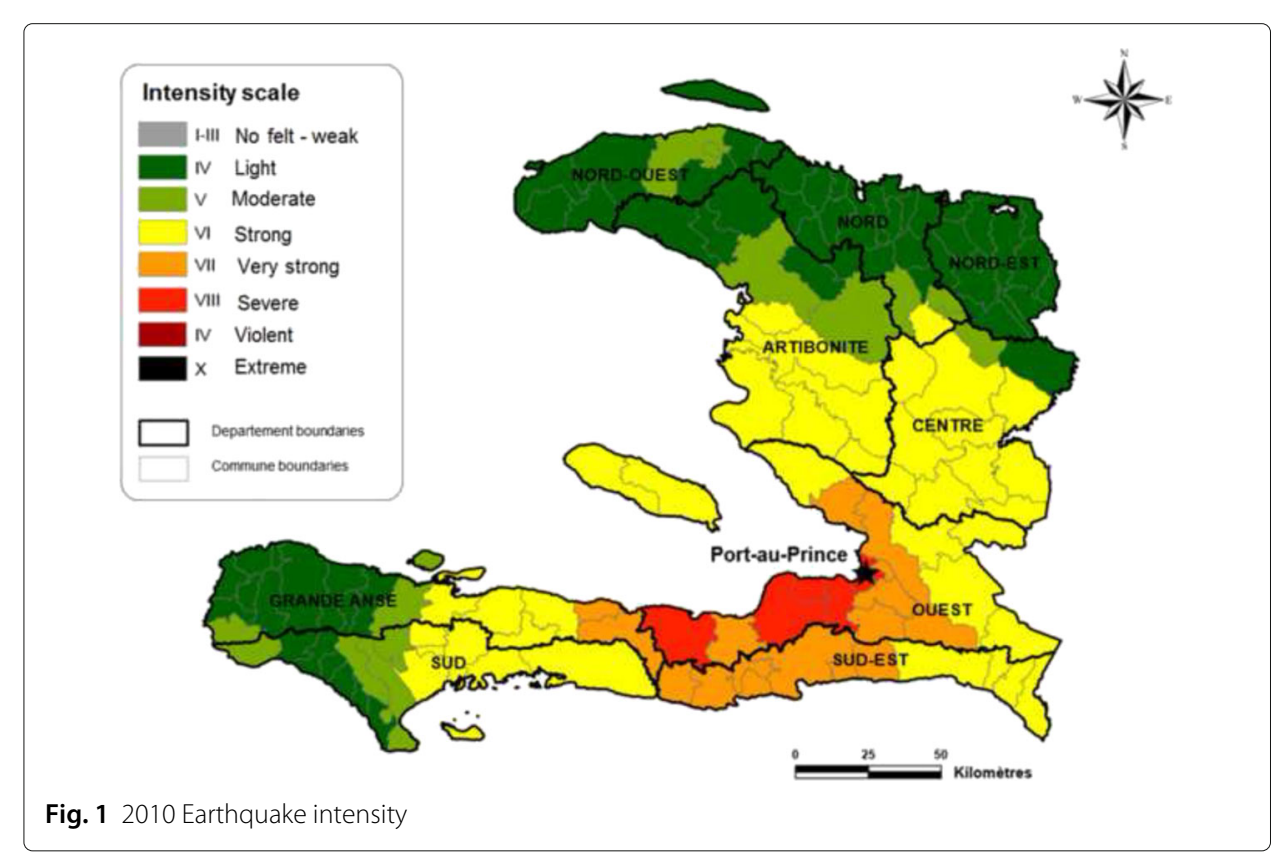


3 months before mid-2012. Reconstruction aid reached just 7\% of the households that suffered extensive damage to their housing. Most of the rubble clearing work had been done by the people themselves, and some of the debris had still not been cleared. All in all, the aid provided by the institutions was short-term emergency aid, heavily oriented to the most directly and stronger hit areas, but not effective in targeting the most vulnerable people in these directly affected areas and even neglecting the indirectly affected ones (Herrera et al. 2014).

The Haitian education sector was one of the sectors most severely affected by the 2010 earthquake, suffering great losses in terms of both infrastructure and manpower (GTEF 2011). According to the Ministry of National Education and Professional Training (MENFP), 4268 education infrastructure (schools, training centers, and institutions of higher education) were destroyed or structurally affected and most all services were suspended until April of 2010. The Economic and Social Assistance Fund of Haiti (FAES) was in charge of light infrastructure implementation to facilitate the return to school. As we mentioned above for international assistance, in the absence of recent data, the education programs' focus (e.g., UNICEF's emergency assistance for education services, Ti Manman Cheri, a conditional transfers program for school retention) was mainly geographical and most of the time favored the Metropolitan area (Lamaute-Brisson 2013). Beyond the response to the emergency situation, the principle of universal access to primary education was reiterated in the operational plan for founding the Haitian education system (2010-2015). ${ }^{10}$ This recommendation finds its translation in the Programme of Free and Compulsory Universal Schooling (PSUGO)-also called Lekòl Timoun yo-released in 2011. PSUGO aims to increase and sustain demand for education with immediate effects, while the change in quality is slower. During the first year, the achievement was mainly in two departments, West (including the Metropolitan area) and Artibonite. According to MENFP, between 2010 and 2013, 288 schools were built (or rebuilt), 108 in the West department. The formation and recruitment of well-qualified teachers is still a challenge in itself despite the efforts that have been initiated (4123 teachers were recruited in 2012-2013; the target is 8000 at the end of the PSUGO program).

\section{Data}

This study combines data from two different sources: the first is the ECVMAS householdlevel data; the second is the magnitude and location measures of the 2010 earthquake from the US Geological Survey.

This paper is based on the information collected during an extended fieldwork aimed at designing, coordinating, and implementing the first nationwide survey about living conditions and labor market after the 2010 earthquake. The Post Earthquake Living Conditions Survey (ECVMAS) consists of 4950 households including 23,775 individuals interviewed in the second half of 2012. This original dataset covers the entire country and is representative at the department level and Metropolitan area and other urban area and rural level. ${ }^{11}$ While $22 \%$ of the total population lives in the metropolitan area of Port-au-Prince, the capital, slightly over half (52\%) lives in rural areas; the rest resides in other urban areas (Herrera et al. 2014).

The 2012 Haiti ECVMAS questionnaire was a variation on the 1-2-3 Survey methodology to measure the informal economy and poverty (Razafindrakoto et al. 2009). This survey contains quantitative information on household consumption expenditures, 
production, income, and assets. We made two major adjustments to this generic framework. The first tailored the questionnaire to Haitian circumstances. The second change was made to include the upheavals caused by the earthquake. Specific earthquakerelated issues were considered, such as the disaster's direct impact, household response strategies, aid received, other hazards, and perceived shocks as well as residential and employment pathways (before and after the earthquake) (Herrera et al. 2014).

The indicator of score damage of the dwelling corresponds to the responses of the head of the household to the question "What part (roof, walls and/or ground) of this house was damaged by the earthquake and with what intensity $(0=$ no damage to $3=$ totally destroyed)." The final indicator of score damage is the sum of these three variables and ranges from $0=$ no damage to $9=$ complete destruction. ${ }^{12}$

We use a unique database containing information of children aged 10-17 years. There is a consensus on the upper bounds of this age bracket as the UNICEF Convention on the rights of the child defines a "child" as a person below the age of 18, which is also the legal age for adulthood in Haiti. The lower bound of the age bracket responds instead to a feature of the data. In our data, children younger than 10 were not interviewed directly and the information provided by the household head is less detailed for them.

Several issues arise in using household survey data to examine child labor supply. First, there is the general question about who should be asked about children's labor supply. Edmonds (2007) argues that while participation in the labor market is less likely to be subject to measurement error, information about children's working hours is expected to be difficult to gauge. Second, household surveys might overestimate the number of children that neither work nor attend school. Biggeri et al. (2003) show that the measurement error in activities, especially mismeasurement of domestic work, unemployment, and unobserved health issues, are responsible for a significant part of the idle status. ECVMAS' uniqueness yields in that it includes information not only on children's work and school attendance but also on their studies and chores activities. Moreover, interviewers asked directly to every child aged 10 or more years how many hours they spend working, studying, or doing household chores during the reference week, which is expected to reduce measurement error for underreporting. ${ }^{13}$

The ECVMAS survey includes also key retrospective questions corresponding to the period just before the 2010 earthquake, allowing us to account for initial conditions and changes in the household's and child's characteristic between the 2010 earthquake and the time of interview. The data quality literature stresses that when a phenomenon of large magnitude happens, the risk of measurement error associated to recall is reduced (De Nicola and Giné X 2014; Dex 1995). According to (Brown and Kulik 1977)'s "flashbulb" memories theory, a highly surprising and consequential event, like the 2010 earthquake, raises memories that show little forgetting (Winograd and Neisser 2006). Moreover, the survey methodology literature testing the reliability and validity of recalled information in household surveys argues that including landmark events to improve respondents' recall ability, as "the salience of the event," appears to have had the largest effects on data quality (De Nicola and Giné X 2014). For instance, Dex (1995) shows that "keeping to important events over a recall period of a few years, therefore, is one way of producing recall data of the same quality as concurrent data, for many subjects." We also use the recall data on owned assets in the 2012 ECVMAS survey to create a metric of 
households' welfare in 2010. As all variables on owned assets are dummy variables, we rely on multiple correspondence analysis (MCA) methodology, more suited to analyze categorical variables (Benzecri and et al 1973; Asselin and Anh 2008; Asselin 2009; Booysen et al. 2008), to create our composite asset index. The construction of the asset index was based on binary indicators on 12 private household assets. Table 8 in the Appendix provides descriptive statistics about asset ownership in 2010 and 2012 (columns (3) and (4) and ACM weights for each index component (column (5))). Those components that reflect higher living standards, such as owning an asset, contribute positively to the household's asset index score, while not owning one decreases it.

Additionally, we merged at the primary sampling unit's level (using geographic information data) the ECVMAS data with measures of ground motion strength, made available by the USGS. ${ }^{14}$ Peak ground acceleration (PGA) is a common geological measure of local hazard caused by earthquakes, which can be interpreted as the maximum acceleration experienced by a physical body (e.g., building) on the ground during the course of the earthquake motion. PGA is considered as a good measure of hazard for buildings up to about seven floors, which is the case of most buildings in Haiti. For Haiti, PGA is calculated as a log-linear function of distance to the epicenter and estimated parameters using data from previous earthquakes. ${ }^{15}$ For each PSU in Haiti, we count with a PGA measure of the 2010 earthquake. This was assigned to each household in the ECVMAS sample, so we have a measure of the earthquake's intensity experienced in the PSU where they were living when the disaster occurred.

The final sample used in this paper consists of 3833 children (with complete information on the relevant variables for the analysis), who in 2012 (i) were aged between 10 and 17 years old ( $18 \%$ of the total population), (ii) were part of the same household with whom they lived at the time of the earthquake, and (iii) were living in the same dwelling or community where they lived at the time of the earthquake. These criteria were mainly considered to minimize the chance of omitted variables biasing our estimates. Table 1 below shows basic descriptive statistics for the selected sample.

In 2012, almost one out of every four children in our sample work and almost one out of every five combined work with school activities. On average, children who work spend only $3 \mathrm{~h}$ less work than the number of hours that children who study spend studying (15 versus $18 \mathrm{~h}$ weekly). The number of hours for domestic work are also relatively high (10 $\mathrm{h}$ weekly). On average, the earthquake damage score and the peak ground acceleration indicators show low damage and intensity of the 2010 earthquake. However, as it was mentioned above, the impact of the shock was highly heterogeneous within the country.

Although most of children in our sample are a son or daughter of the household head (70\%), an important proportion (18\%) are living with a household head with whom they are weakly biologically related (daughter/son in law, aunt/uncle, nephew/niece, cousin, or other relative). According to Hamilton's rule (Hamilton 1964), a longer biological relationship with the decision-maker in the household puts children at higher risk of receiving less resources. Moreover, Table 1 shows an increase of at least 15 p.p. in the labor market participation of children between 2010 and 2012. This might due to a simple age effect or a response of the household to the negative effects of the earthquake on their welfare.

Table 1 shows the low level of education achievement in the country. In our sample, $73 \%$ of heads of the household have less than secondary education. Moreover, $81 \%$ of households mention they keep living in the house where they lived at the time of the 2010 
Table 1 Descriptive statistics

\begin{tabular}{|c|c|c|c|c|}
\hline & 2010 mean & (Std. dev.) & 2012 mean & (Std. dev.) \\
\hline Idle (yes $=1$ ) & - & - & 0.066 & $(0.249)$ \\
\hline School only (yes = 1) & - & - & 0.705 & $(0.456)$ \\
\hline Work only (yes $=1$ ) & - & - & 0.037 & $(0.189)$ \\
\hline School and work (yes = 1) & - & - & 0.191 & $(0.393)$ \\
\hline Hours studying (weekly) & - & - & 18.285 & $(11.563)$ \\
\hline Hours market work (weekly) & - & - & 15.400 & $(10.412)$ \\
\hline Hours domestic work (weekly) & - & - & 9.944 & (9.138) \\
\hline Earthquake damage score (0-9) & - & - & 1.518 & $(2.428)$ \\
\hline Peak ground acceleration & - & - & 0.166 & $(0.152)$ \\
\hline Age & - & - & 13.550 & $(2.230)$ \\
\hline Sex $($ male $=1)$ & - & - & 0.515 & $(0.500)$ \\
\hline Child's age order within the household & - & - & 4.685 & $(1.887)$ \\
\hline Child was economically active (yes $=1$ ) & 0.079 & $(0.270)$ & - & - \\
\hline $\begin{array}{l}\text { Relation to head of household = sonldaughter } \\
(\text { yes }=1 \text { ) }\end{array}$ & - & - & 0.704 & $(0.456)$ \\
\hline $\begin{array}{l}\text { Relation to head of household = close relative } \\
(\text { yes }=1 \text { ) }\end{array}$ & - & - & 0.120 & $(0.325)$ \\
\hline $\begin{array}{l}\text { Relation to head of household = other relative } \\
(\text { yes }=1 \text { ) }\end{array}$ & - & - & 0.155 & $(0.362)$ \\
\hline $\begin{array}{l}\text { Relation to head of household = domestic } \\
\text { employee (yes }=1 \text { ) }\end{array}$ & - & - & 0.008 & $(0.087)$ \\
\hline $\begin{array}{l}\text { Relation to head of household = other relation- } \\
\text { ship }(\text { yes }=1 \text { ) }\end{array}$ & - & - & 0.013 & $(0.114)$ \\
\hline Sex of head of household $($ male $=1)$ & - & - & 0.554 & $(0.497)$ \\
\hline $\begin{array}{l}\text { Head of household education level = none or } \\
\text { pre-school (yes = 1) }\end{array}$ & - & - & 0.398 & $(0.489)$ \\
\hline $\begin{array}{l}\text { Head of household education level = primary } \\
(\text { yes }=1)\end{array}$ & - & - & 0.336 & $(0.472)$ \\
\hline $\begin{array}{l}\text { Head of household education level = secondary } \\
\text { or more (yes }=1 \text { ) }\end{array}$ & - & - & 0.266 & $(0.442)$ \\
\hline Live in the same house (yes $=1$ ) & - & - & 0.809 & $(0.393)$ \\
\hline $\begin{array}{l}\text { Household has received any type of assistance } \\
(\text { yes }=1)\end{array}$ & - & - & 0.723 & $(0.448)$ \\
\hline Number of negative economic shock & - & - & 2.089 & $(1.038)$ \\
\hline Members living in a temporary camp (\%) & - & - & 0.022 & $(0.131)$ \\
\hline $\begin{array}{l}\text { Has any household member suffered physical } \\
\text { damage (yes }=1 \text { ) }\end{array}$ & - & - & 0.092 & $(0.290)$ \\
\hline Household size & 6.640 & $(2.605)$ & 6.665 & $(2.681)$ \\
\hline $\begin{array}{l}\text { Number of children aged } 0 \text { to } 10 \text { years in house- } \\
\text { hold }\end{array}$ & - & - & 1.404 & $(1.338)$ \\
\hline Durable assets index & -0.083 & $(0.888)$ & -0.045 & $(0.883)$ \\
\hline House ownership (yes = 1) & 0.734 & $(0.442)$ & 0.768 & $(0.422)$ \\
\hline Metropolitan area (yes $=1$ ) & - & - & 0.194 & $(0.396)$ \\
\hline Other urban area (yes $=1$ ) & - & - & 0.257 & $(0.437)$ \\
\hline Rural (yes = 1) & - & - & 0.548 & $(0.498)$ \\
\hline
\end{tabular}

Note: sample weights used. The sample size corresponds to 3833 children 10-17 years old

earthquake. Table 1 also indicates that $72 \%$ of the households where the children in our sample live received any type of assistance after the earthquake. ${ }^{16}$ On top on the earthquake, the average number of negative economic shocks received by the household in the last 12 months is two, which might also affect the current decision of the household about children's time use. Two percent of the children in our sample have a household member 
that lives in one of the shelters built after the earthquake. This variable is considered in the analysis because living in a shelter might be a household strategy to keep receiving potential additional services around them. As the bottom variables in Table 1 show, the children in our sample are mainly located in rural areas (54\%) and urban areas different to Port-au-Prince (27\%).

\section{Identification strategy}

This section presents the different empirical strategies adopted to study whether household vulnerability at the time of the earthquake affects the household's decision about children's time allocation about 3 years after the shock. According to the Pressure and Release (PAR) model (Blaikie et al. 2014), the impact of a natural disaster can be seen as the intersection of two major forces: a natural hazard event and the processes generating vulnerability. As our data allow us to distinguish between the natural hazard event, which is the physical intensity of the 2010 earthquake, and the natural disaster impact (measured by a damage score of the dwelling), we first estimate vulnerability as the residual of a standard OLS model:

$$
g_{c}=\theta_{0}+\theta_{1} p g a_{c}+\theta_{2} w_{c}+v_{c}
$$

In Eq. (1), our measure of damage $g$ corresponds to the degree of destruction of household c's dwelling, resulting from the occurrence of the earthquake and expressed on a scale from 0 (no damage) to 9 (total damage). pga stands for the physical intensity of the 2010 earthquake and $w$ for an asset index of $c$ at the time of the earthquake. The error term, $v$, includes the remaining dwelling damage that cannot be explained by the intensity of the natural hazard and the asset indicator of wealth. ${ }^{17}$ This is our indicator of household (revealed) vulnerability at the time of the earthquake.

In addition to affect the decision about children's time through the level of vulnerability of the household at the moment of the shock, the 2010 earthquake in Haiti might impact the decision through several additional channels. For instance, it might have affected production factors, increasing transportation and transaction costs and destroying markets; the demographic composition of households; children's physical and mental health; the supply of services; and international aid. This clearly invalidates the use of the earthquake's intensity as an instrumental variable (IV) to deal with the potential endogeneity of household vulnerability.

To wash away unobserved components that might have affected both the household's vulnerability and the decision about children's time, we include children and household's characteristics before the earthquake and variables that might have changed as a consequence of the earthquake between 2010 and 2012. Moreover, we also account for unobserved heterogeneity at the community level (e.g., local labor conditions, social norms). In contrast, to avoid endogeneity by reverse causality, we do not include variables of 2012.

An additional concern is the joint determination of schooling and work decisions. To account for the correlation of the error terms in the equations of the discrete outcome variables, we use a multinomial logit (MNL) model. The outcome, $d$, for child $i$ corresponds to one of four unordered alternatives: idle, school only, work only, and school and work. The probability that the decision for child $i$ is alternative $j$, conditional on the $x_{i}$, is: 


$$
p_{i j}=\operatorname{Pr}\left(d_{i}=j\right)=\frac{\exp \left(x_{i}^{\prime} \beta_{j}\right)}{\sum_{l=1}^{m} \exp \left(x_{i}^{\prime} \beta_{l}\right)}, \quad j=1, . ., 4, \quad i=1, . ., N
$$

Similarly, to allow for correlation in errors between the equations of hours of study and market and domestic work, we estimate a seemingly unrelated (SUR) model. The error terms are assumed to have zero mean and to be independent across individuals, and to allow them to be heteroskedastic, at estimation, we resample over individuals and calculate bootstrapped standard errors. In this case, the $j$ th equation for child $i$ is:

$$
h_{i j}=x_{i j}^{\prime} \alpha_{j}+u_{i j}
$$

Finally, we estimate OLS models for both schooling and work decisions and number of hours, which include PSU-level fixed-effects (FEs) accounting for unobservable characteristics at the PSU level (e.g., aid response, local labor markets condition, social norms):

$$
y_{i j}=x_{i j}^{\prime} \gamma_{j}+\delta_{j} c+\epsilon_{i j}
$$

Even though this specification does not account for correlation of error terms between equations, the estimators provide the advantage of having well-understood properties and the results are comparable to previous studies.

\section{Results}

This section starts discussing the estimation of households' vulnerability and then presents two sets of regressions on children's time allocation. Being heavily hit by the earthquake (measured through PGA) strongly affects the dwelling damage score, even after comparing households equally wealthy at the time of the earthquake (measured through the asset index) (Table 2). ${ }^{18}$

In addition, the first set (Table 3) includes the MNL estimates of the household decision about children's time allocation in terms of idle, school only, work only, and school and work. The second set (Table 4) corresponds to the SUR estimation of the number of hours for studying and market and domestic work. Moreover, it discusses the relationship of other characteristics of children, households, and communities and the decision about children's time allocation.

On the one hand, the Wald test at the bottom of Table 3 shows that the vulnerability index is jointly significant across equations at the 95\% level. In addition, it shows that an increase in one unit of vulnerability at the time of the earthquake is associated with a

Table 2 Household's vulnerability

\begin{tabular}{ll}
\hline & Earthquake damage score \\
\hline Peak ground acceleration & $6.621^{* * *}$ \\
Durable assets index, 2010 & $(0.539)$ \\
& $-0.279^{* * *}$ \\
Constant & $(0.064)$ \\
& $0.499^{* * *}$ \\
Observations & $(0.093)$ \\
R-squared & 3833 \\
\hline
\end{tabular}

Note: standard errors clustered at the PSU level are in parentheses ${ }^{*} p<0.1,{ }^{* *} p<0.05,{ }^{* * *} p<0.01$ 
Table 3 MNL model for children's time allocation

\begin{tabular}{|c|c|c|c|}
\hline & Idle & Work only & School and work \\
\hline & \multicolumn{3}{|c|}{ (base category = school only) } \\
\hline Household vulnerability index & $\begin{array}{l}2.334^{*} \\
(1.124)\end{array}$ & $\begin{array}{l}6.681^{* * *} \\
(4.579)\end{array}$ & $\begin{array}{l}1.427 \\
(0.607)\end{array}$ \\
\hline Age & $\begin{array}{l}1.205^{* * *} \\
(0.054)\end{array}$ & $\begin{array}{l}1.090 \\
(0.102)\end{array}$ & $\begin{array}{l}1.059^{*} \\
(0.036)\end{array}$ \\
\hline Sex $($ male $=1$ and at age $=13.55)$ & $\begin{array}{l}0.668^{* * *} \\
(0.092)\end{array}$ & $\begin{array}{l}1.877^{* * *} \\
(0.364)\end{array}$ & $\begin{array}{l}1.470^{* * *} \\
(0.147)\end{array}$ \\
\hline Age ${ }^{*}$ sex & $\begin{array}{l}0.898 \\
(0.062)\end{array}$ & $\begin{array}{l}1.028 \\
(0.101)\end{array}$ & $\begin{array}{l}1.039 \\
(0.043)\end{array}$ \\
\hline Child's age order within the household & $\begin{array}{l}1.202^{* *} \\
(0.105)\end{array}$ & $\begin{array}{l}0.869 \\
(0.113)\end{array}$ & $\begin{array}{l}0.831^{* * *} \\
(0.047)\end{array}$ \\
\hline Child was economically active, 2010 (yes $=1$ ) & $\begin{array}{l}3.810^{* * *} \\
(1.121)\end{array}$ & $\begin{array}{l}31.606^{* * *} \\
(9.175)\end{array}$ & $\begin{array}{l}16.003^{* * *} \\
(3.283)\end{array}$ \\
\hline Relation to head of household = close relative $($ yes $=1$ ) & $\begin{array}{l}1.526^{* *} \\
(0.314)\end{array}$ & $\begin{array}{l}0.673 \\
(0.292)\end{array}$ & $\begin{array}{l}0.866 \\
(0.157)\end{array}$ \\
\hline Relation to head of household = other relative (yes $=1$ ) & $\begin{array}{l}1.759^{* * *} \\
(0.336)\end{array}$ & $\begin{array}{l}1.331 \\
(0.361)\end{array}$ & $\begin{array}{l}0.641 \text { ** } \\
(0.115)\end{array}$ \\
\hline Relation to head of household = domestic employee $($ yes $=1$ ) & $\begin{array}{l}4.882^{* *} \\
(3.014)\end{array}$ & $\begin{array}{l}6.570^{* *} \\
(5.554)\end{array}$ & $\begin{array}{l}1.925 \\
(0.871)\end{array}$ \\
\hline Relation to head of household = other relationship $($ yes $=1$ ) & $\begin{array}{l}1.312 \\
(0.771)\end{array}$ & $\begin{array}{l}3.417^{* * *} \\
(1.887)\end{array}$ & $\begin{array}{l}1.126 \\
(0.533)\end{array}$ \\
\hline Sex of head of household (male $=1$ ) & $\begin{array}{l}0.964 \\
(0.181)\end{array}$ & $\begin{array}{l}1.735^{* *} \\
(0.469)\end{array}$ & $\begin{array}{l}1.889^{* * *} \\
(0.245)\end{array}$ \\
\hline Head of household education level = primary $($ yes $=1$ ) & $\begin{array}{l}0.795 \\
(0.159)\end{array}$ & $\begin{array}{l}0.530^{* *} \\
(0.146)\end{array}$ & $\begin{array}{l}0.774^{*} \\
(0.105)\end{array}$ \\
\hline Head of household education level = secondary or more (yes $=1$ ) & $\begin{array}{l}0.357^{* * *} \\
(0.084)\end{array}$ & $\begin{array}{l}0.153^{* * *} \\
(0.058)\end{array}$ & $\begin{array}{l}0.670^{* *} \\
(0.114)\end{array}$ \\
\hline Live in the same house $($ yes $=1$ ) & $\begin{array}{l}1.290 \\
(0.282)\end{array}$ & $\begin{array}{l}1.092 \\
(0.424)\end{array}$ & $\begin{array}{l}0.991 \\
(0.199)\end{array}$ \\
\hline Household has received any type of assistance (yes $=1$ ) & $\begin{array}{l}0.711^{* *} \\
(0.122)\end{array}$ & $\begin{array}{l}0.988 \\
(0.269)\end{array}$ & $\begin{array}{l}1.078 \\
(0.155)\end{array}$ \\
\hline Number of negative economic shock & $\begin{array}{l}0.926 \\
(0.085)\end{array}$ & $\begin{array}{l}1.327^{* *} \\
(0.156)\end{array}$ & $\begin{array}{l}1.289^{* * *} \\
(0.087)\end{array}$ \\
\hline Members living in a temporary camp (\%) & $\begin{array}{l}1.419 \\
(0.534)\end{array}$ & $\begin{array}{l}1.328 \\
(0.982)\end{array}$ & $\begin{array}{l}0.475 \\
(0.218)\end{array}$ \\
\hline Has any household member suffered physical damage (yes $=1$ ) & $\begin{array}{l}0.753 \\
(0.226)\end{array}$ & $\begin{array}{l}1.001 \\
(0.334)\end{array}$ & $\begin{array}{l}0.828 \\
(0.187)\end{array}$ \\
\hline \multirow[t]{2}{*}{ Household size, 2010} & $0.830^{* *}$ & 0.987 & $1.163^{* * *}$ \\
\hline & $(0.069)$ & $(0.096)$ & $(0.056)$ \\
\hline Number of children aged 0 to 10 years in household & $\begin{array}{l}1.281^{* *} \\
(0.129)\end{array}$ & $\begin{array}{l}1.090 \\
(0.132)\end{array}$ & $\begin{array}{l}0.869^{* *} \\
(0.058)\end{array}$ \\
\hline Durable assets index, 2010 & $\begin{array}{l}0.537^{* * *} \\
(0.104)\end{array}$ & $\begin{array}{l}0.610 \\
(0.254)\end{array}$ & $\begin{array}{l}0.736^{* * *} \\
(0.083)\end{array}$ \\
\hline House ownership, 2010 (yes $=1$ ) & $\begin{array}{l}0.812 \\
(0.166)\end{array}$ & $\begin{array}{l}1.686 \\
(0.664)\end{array}$ & $\begin{array}{l}1.698^{* * *} \\
(0.267)\end{array}$ \\
\hline Constant & $\begin{array}{l}0.008^{* * *} \\
(0.006)\end{array}$ & $\begin{array}{l}0.002^{* * *} \\
(0.003)\end{array}$ & $\begin{array}{l}0.022^{* * *} \\
(0.015)\end{array}$ \\
\hline \multicolumn{2}{|l|}{$\begin{array}{l}\text { Observations } \\
\text { Pseudo R-squared } \\
\text { Wald test of the significance of the vulnerability index, } \operatorname{chi}^{2}(3) \\
\text { PSU FE }\end{array}$} & $\begin{array}{l}3833 \\
0.155 \\
8.90 \\
\text { No }\end{array}$ & \\
\hline
\end{tabular}

Note: standard errors clustered at the PSU level are in parentheses

${ }^{*} p<0.1,{ }^{* *} p<0.05,{ }^{* * *} p<0.01$

substantial increase in the odds of choosing work only rather than school only. Similarly, but in lower magnitude, more vulnerability is associated with an increase in the odds of the child of being idle rather than attending school. 
Table 4 SUR model for children's time allocation

\begin{tabular}{|c|c|c|c|}
\hline & Hours studying & Hours working & Hours hh chores \\
\hline Household vulnerability index & $\begin{array}{l}-3.555^{* * *} \\
(1.300)\end{array}$ & $\begin{array}{l}1.206^{*} \\
(0.621)\end{array}$ & $\begin{array}{l}4.940^{* * *} \\
(0.986)\end{array}$ \\
\hline Age & $\begin{array}{l}-0.016 \\
(0.089)\end{array}$ & $\begin{array}{l}0.264^{* * *} \\
(0.055)\end{array}$ & $\begin{array}{l}0.281^{* * *} \\
(0.076)\end{array}$ \\
\hline Sex $($ male $=1$ and at age $=13.55)$ & $\begin{array}{l}-0.514 \\
(0.377)\end{array}$ & $\begin{array}{l}1.211^{* * *} \\
(0.223)\end{array}$ & $\begin{array}{l}-4.205^{* * *} \\
(0.317)\end{array}$ \\
\hline Child's age order within the household & $\begin{array}{l}-0.150 \\
(0.169)\end{array}$ & $\begin{array}{l}-0.480^{* * *} \\
(0.125)\end{array}$ & $\begin{array}{l}-0.461^{* * *} \\
(0.156)\end{array}$ \\
\hline Child was economically active, 2010 (yes = 1) & $\begin{array}{l}-3.925^{* * *} \\
(0.546)\end{array}$ & $\begin{array}{l}10.304^{* * *} \\
(0.872)\end{array}$ & $\begin{array}{l}2.026^{* * *} \\
(0.709)\end{array}$ \\
\hline Relation to head of household $=$ close relative $($ yes $=1$ ) & $\begin{array}{l}-1.286^{* *} \\
(0.569)\end{array}$ & $\begin{array}{l}-0.233 \\
(0.383)\end{array}$ & $\begin{array}{l}-0.050 \\
(0.461)\end{array}$ \\
\hline Relation to head of household $=$ other relative $($ yes $=1$ ) & $\begin{array}{l}-1.099^{*} \\
(0.590)\end{array}$ & $\begin{array}{l}-0.564 \\
(0.347)\end{array}$ & $\begin{array}{l}1.327^{* * *} \\
(0.436)\end{array}$ \\
\hline Relation to head of household = domestic employee $($ yes $=1)$ & $\begin{array}{l}-6.624^{* * *} \\
(1.776)\end{array}$ & $\begin{array}{l}2.087 \\
(1.615)\end{array}$ & $\begin{array}{l}7.703^{* * *} \\
(2.534)\end{array}$ \\
\hline Relation to head of household = other relationship (yes $=1$ ) & $\begin{array}{l}-4.670^{* * * *} \\
(1.562)\end{array}$ & $\begin{array}{l}0.608 \\
(0.919)\end{array}$ & $\begin{array}{l}2.049^{*} \\
(1.082)\end{array}$ \\
\hline Sex of head of household (male $=1$ ) & $\begin{array}{l}-0.750^{* *} \\
(0.381)\end{array}$ & $\begin{array}{l}1.098^{* * *} \\
(0.240)\end{array}$ & $\begin{array}{l}1.331^{* * *} \\
(0.305)\end{array}$ \\
\hline Head of household education level = primary $($ yes $=1$ ) & $\begin{array}{l}0.758^{*} \\
(0.425)\end{array}$ & $\begin{array}{l}-0.463 \\
(0.291)\end{array}$ & $\begin{array}{l}-0.256 \\
(0.349)\end{array}$ \\
\hline Head of household education level = secondany or more $($ yes $=1$ ) & $\begin{array}{l}3.822 * * * \\
(0.585)\end{array}$ & $\begin{array}{l}-0.736^{* *} \\
(0.310)\end{array}$ & $\begin{array}{l}-1.214^{* * *} \\
(0.405)\end{array}$ \\
\hline Live in the same house (yes $=1$ ) & $\begin{array}{l}-1.240^{*} \\
(0.678)\end{array}$ & $\begin{array}{l}0.029 \\
(0.368)\end{array}$ & $\begin{array}{l}0.522 \\
(0.445)\end{array}$ \\
\hline Household has received any type of assistance (yes $=1$ ) & $\begin{array}{l}-0.155 \\
(0.428)\end{array}$ & $\begin{array}{l}-0.190 \\
(0.246)\end{array}$ & $\begin{array}{l}-0.455 \\
(0.341)\end{array}$ \\
\hline Number of negative economic shock & $\begin{array}{l}-0.224 \\
(0.190)\end{array}$ & $\begin{array}{l}0.551^{* * *} \\
(0.101)\end{array}$ & $\begin{array}{l}1.174^{* * *} \\
(0.138)\end{array}$ \\
\hline Members living in a temporary camp (\%) & $\begin{array}{l}4.974 * * * \\
(1.251)\end{array}$ & $\begin{array}{l}-0.296 \\
(0.705)\end{array}$ & $\begin{array}{l}-1.925^{* * *} \\
(0.682)\end{array}$ \\
\hline Has any household member suffered physical damage (yes $=1$ ) & $\begin{array}{l}2.862^{* * *} \\
(0.686)\end{array}$ & $\begin{array}{l}-0.451 \\
(0.345)\end{array}$ & $\begin{array}{l}0.071 \\
(0.468)\end{array}$ \\
\hline Household size, 2010 & $\begin{array}{l}-0.312^{* *} \\
(0.145)\end{array}$ & $\begin{array}{l}0.385^{* * *} \\
(0.113)\end{array}$ & $\begin{array}{l}-0.129 \\
(0.134)\end{array}$ \\
\hline Number of children aged 0 to 10 years in household & $\begin{array}{l}-0.332^{*} \\
(0.182)\end{array}$ & $\begin{array}{l}-0.315^{* *} \\
(0.130)\end{array}$ & $\begin{array}{l}0.307^{* *} \\
(0.153)\end{array}$ \\
\hline Durable assets index, 2010 & $\begin{array}{l}2.719^{* * *} \\
(0.289)\end{array}$ & $\begin{array}{l}-0.283^{* *} \\
(0.140)\end{array}$ & $\begin{array}{l}-0.896^{* * *} \\
(0.129)\end{array}$ \\
\hline House ownership, 2010 (yes $=1$ ) & $\begin{array}{l}-2.639^{* * * *} \\
(0.562)\end{array}$ & $\begin{array}{l}1.074 * * * \\
(0.272)\end{array}$ & $\begin{array}{l}1.002^{* * *} \\
(0.351)\end{array}$ \\
\hline Constant & $\begin{array}{l}17.017^{* * *} \\
(1.647)\end{array}$ & $\begin{array}{l}-3.836^{* * *} \\
(1.036)\end{array}$ & $\begin{array}{l}4.253^{* * *} \\
(1.343)\end{array}$ \\
\hline $\begin{array}{l}\text { Observations } \\
\text { R-squared } \\
\text { PSU FE }\end{array}$ & $\begin{array}{l}3833 \\
0.171 \\
\text { No }\end{array}$ & $\begin{array}{l}3833 \\
0.187 \\
\text { No }\end{array}$ & $\begin{array}{l}3833 \\
0.135 \\
\text { No }\end{array}$ \\
\hline \multicolumn{4}{|l|}{ Correlation matrix of residuals } \\
\hline $\begin{array}{l}\text { Hours studying } \\
\text { Hours working } \\
\text { Hours hh chores }\end{array}$ & $\begin{array}{l}1.000 \\
-0.098 \\
-0.085\end{array}$ & $\begin{array}{l}- \\
1.000 \\
0.111\end{array}$ & $\begin{array}{l}- \\
- \\
1.000\end{array}$ \\
\hline
\end{tabular}

Note: bootstrapped standard errors are in parentheses (400 replications). Breusch-Pagan test of independence: $\operatorname{chi}^{2}(3)=100.625, \operatorname{Pr}=0.000$

${ }^{*} p<0.1,{ }^{* *} p<0.05,{ }^{* * *} p<0.01$ 
On the other hand, the bottom part of Table 4 shows that the errors in the three equations of hours are correlated (i.e., the Breusch-Pagan Lagrange multiplier test for error independence is rejected at the $99 \%$ level). Moreover, it shows that vulnerability at the time of the earthquake is negatively associated with a substantial reduction in the number of weekly hours children devote to study ( $3.5 \mathrm{~h})$. In contrast, it is positively associated with a substantial increase in the hours dedicated to domestic $(5 \mathrm{~h})$ and market work (1 h).

To be able to compare our findings to previous studies and to account for unobserved heterogeneity at the PSU level, we present (Tables 5 and 6) the linear probability models for separated outcomes including FE at the PSU level in Eq. $4 .{ }^{19}$ When the correlation of the error terms is not taken into account, we find that more vulnerability is associated with a reduction in 11 p.p. in the probability of exclusively attending school and with an increase in 6 p.p. in the probability of working only. Similarly, more vulnerability is associated with a reduction in $3 \mathrm{~h}$ of studying and an increase in $4 \mathrm{~h}$ of household chores. Tables 12 and 13 in the Appendix also show estimations by geographical area. Both the reduction in the probability of exclusively attending school and the increase in the probability of working only seem to be driven by children in rural areas. Similarly, we find that the association of vulnerability and more hours of household chores seems to be driven by children living in rural and other non-metropolitan areas of the country. ${ }^{20}$

Although our main variable of interest is the household's vulnerability, it is interesting to explore how children's individual and other household's characteristics are related to the decision about children's time allocation. Overall, we find that an additional year of age is associated to a larger likelihood of working (2 p.p.) and working and studying (2 p.p.) and to a lower likelihood of studying exclusively (0.5 p.p.). In addition, we find gender differences on the age effect (coefficient on the interaction age $*$ sex). In contrast to girls, for boys, age reduces both the probability of being idle and the number of hours devoted to household chores and increases both the probability of working and studying and the number of hours or market work. For all children, birth order (i.e., being younger in the household) increases the probability of being idle and hours of leisure and reduces the probability of studying and working and hours of study. We also find evidence of strong and significant state-dependence in terms of previous working status. Children who were economically active at the time of the earthquake spend considerably more hours working for the market $(9 \mathrm{~h})$ and domestically $(2 \mathrm{~h})$ and fewer hours studying $(2 \mathrm{~h})$. They are also much less likely to attend school (46 p.p.) and more likely to exclusively work (14 p.p.) and combine school and work (33 p.p.). We also find some evidence of Hamilton's rule. Children who are less related biologically to the household head, in contrast to sons or daughters, spend fewer hours studying and longer hours doing domestic work.

After controlling for the whole set of covariates, we do not find much evidence of characteristics of the household head affecting children's time allocation. We find, however, that children in households where the head of the household has at least secondary education are less likely to work, in contrast to living with a head of the household with no formal education.

We find that receiving more negative economic shocks between 2010 and 2012 affect investments in children's human capital. It apparently makes children to stop attending school exclusively and to start combining it with work activities. It also marginally increases the number of hours for market and domestic work. We also find evidence that 
Table 5 Fixed-effects model, school/work decision

\begin{tabular}{|c|c|c|c|c|}
\hline & Idle & School only & Workonly & School and work \\
\hline Household vulnerability index & $\begin{array}{l}0.033 \\
(0.034)\end{array}$ & $\begin{array}{l}-0.106^{*} \\
(0.060)\end{array}$ & $\begin{array}{l}0.064^{* *} \\
(0.026)\end{array}$ & $\begin{array}{l}0.009 \\
(0.049)\end{array}$ \\
\hline Age & $\begin{array}{l}0.011^{* * *} \\
(0.003)\end{array}$ & $\begin{array}{l}-0.019^{* * *} \\
(0.005)\end{array}$ & $\begin{array}{l}0.003 \\
(0.003)\end{array}$ & $\begin{array}{l}0.004 \\
(0.004)\end{array}$ \\
\hline Sex $($ male $=1$ and at age $=13.55)$ & $\begin{array}{l}-0.027^{* * *} \\
(0.008)\end{array}$ & $\begin{array}{l}-0.036^{* * *} \\
(0.014)\end{array}$ & $\begin{array}{l}0.018^{* * *} \\
(0.006)\end{array}$ & $\begin{array}{l}0.045^{* * *} \\
(0.013)\end{array}$ \\
\hline Age * sex & $\begin{array}{l}-0.008^{* *} \\
(0.004)\end{array}$ & $\begin{array}{l}-0.004 \\
(0.006)\end{array}$ & $\begin{array}{l}0.002 \\
(0.003)\end{array}$ & $\begin{array}{l}0.011^{* *} \\
(0.005)\end{array}$ \\
\hline Child's age order within the household & $\begin{array}{l}0.013^{* * *} \\
(0.004)\end{array}$ & $\begin{array}{l}0.004 \\
(0.008)\end{array}$ & $\begin{array}{l}0.002 \\
(0.004)\end{array}$ & $\begin{array}{l}-0.019^{* * *} \\
(0.007)\end{array}$ \\
\hline Child was economically active, 2010 (yes $=1$ ) & $\begin{array}{l}-0.005 \\
(0.019)\end{array}$ & $\begin{array}{l}-0.461^{* * *} \\
(0.031)\end{array}$ & $\begin{array}{l}0.137^{* * *} \\
(0.028)\end{array}$ & $\begin{array}{l}0.330^{* * *} \\
(0.036)\end{array}$ \\
\hline Relation to head of household $=$ close relative $($ yes $=1$ ) & $\begin{array}{l}0.044^{* *} \\
(0.017)\end{array}$ & $\begin{array}{l}-0.032 \\
(0.028)\end{array}$ & $\begin{array}{l}-0.008 \\
(0.010)\end{array}$ & $\begin{array}{l}-0.004 \\
(0.026)\end{array}$ \\
\hline Relation to head of household $=$ other relative $($ yes $=1$ ) & $\begin{array}{l}0.044^{* * *} \\
(0.015)\end{array}$ & $\begin{array}{l}-0.008 \\
(0.022)\end{array}$ & $\begin{array}{l}0.012 \\
(0.010)\end{array}$ & $\begin{array}{l}-0.049^{* *} \\
(0.019)\end{array}$ \\
\hline Relation to head of household = domestic employee $($ yes $=1$ ) & $\begin{array}{l}0.073 \\
(0.057)\end{array}$ & $\begin{array}{l}-0.007 \\
(0.089)\end{array}$ & $\begin{array}{l}0.072 \\
(0.054)\end{array}$ & $\begin{array}{l}-0.138^{*} \\
(0.082)\end{array}$ \\
\hline Relation to head of household = other relationship $($ yes $=1$ ) & $\begin{array}{l}0.034 \\
(0.040)\end{array}$ & $\begin{array}{l}-0.032 \\
(0.073)\end{array}$ & $\begin{array}{l}0.032 \\
(0.035)\end{array}$ & $\begin{array}{l}-0.034 \\
(0.065)\end{array}$ \\
\hline Sex of head of household $($ male $=1$ ) & $\begin{array}{l}-0.018 \\
(0.012)\end{array}$ & $\begin{array}{l}-0.012 \\
(0.021)\end{array}$ & $\begin{array}{l}-0.003 \\
(0.009)\end{array}$ & $\begin{array}{l}0.032^{*} \\
(0.018)\end{array}$ \\
\hline Head of household education level = primary $($ yes $=1$ ) & $\begin{array}{l}-0.012 \\
(0.014)\end{array}$ & $\begin{array}{l}0.016 \\
(0.024)\end{array}$ & $\begin{array}{l}-0.012 \\
(0.010)\end{array}$ & $\begin{array}{l}0.009 \\
(0.022)\end{array}$ \\
\hline Head of household education level = secondany or more $($ yes $=1$ ) & $\begin{array}{l}-0.025^{*} \\
(0.015)\end{array}$ & $\begin{array}{l}0.022 \\
(0.026)\end{array}$ & $\begin{array}{l}-0.020^{* *} \\
(0.009)\end{array}$ & $\begin{array}{l}0.024 \\
(0.024)\end{array}$ \\
\hline Live in the same house (yes $=1$ ) & $\begin{array}{l}0.009 \\
(0.016)\end{array}$ & $\begin{array}{l}-0.018 \\
(0.029)\end{array}$ & $\begin{array}{l}0.003 \\
(0.013)\end{array}$ & $\begin{array}{l}0.006 \\
(0.026)\end{array}$ \\
\hline Household has received any type of assistance (yes $=1$ ) & $\begin{array}{l}-0.024^{*} \\
(0.012)\end{array}$ & $\begin{array}{l}0.025 \\
(0.024)\end{array}$ & $\begin{array}{l}0.000 \\
(0.009)\end{array}$ & $\begin{array}{l}-0.002 \\
(0.021)\end{array}$ \\
\hline Number of negative economic shock & $\begin{array}{l}-0.004 \\
(0.006)\end{array}$ & $\begin{array}{l}-0.023^{* *} \\
(0.010)\end{array}$ & $\begin{array}{l}0.003 \\
(0.003)\end{array}$ & $\begin{array}{l}0.024 * * * \\
(0.009)\end{array}$ \\
\hline Members living in a temporary camp (\%) & $\begin{array}{l}-0.085 \\
(0.059)\end{array}$ & $\begin{array}{l}-0.036 \\
(0.106)\end{array}$ & $\begin{array}{l}0.042 \\
(0.038)\end{array}$ & $\begin{array}{l}0.079 \\
(0.086)\end{array}$ \\
\hline Has any household member suffered physical damage (yes $=1$ ) & $\begin{array}{l}-0.026 \\
(0.017)\end{array}$ & $\begin{array}{l}0.011 \\
(0.028)\end{array}$ & $\begin{array}{l}0.017 \\
(0.012)\end{array}$ & $\begin{array}{l}-0.002 \\
(0.027)\end{array}$ \\
\hline Household size, 2010 & $\begin{array}{l}-0.010^{* *} \\
(0.004)\end{array}$ & $\begin{array}{l}-0.004 \\
(0.007)\end{array}$ & $\begin{array}{l}-0.003 \\
(0.003)\end{array}$ & $\begin{array}{l}0.017^{* * *} \\
(0.006)\end{array}$ \\
\hline Number of children aged 0 to 10 years in household & $\begin{array}{l}0.014^{* *} \\
(0.006)\end{array}$ & $\begin{array}{l}0.006 \\
(0.010)\end{array}$ & $\begin{array}{l}0.002 \\
(0.004)\end{array}$ & $\begin{array}{l}-0.022^{* *} \\
(0.009)\end{array}$ \\
\hline Durable assets index, 2010 & $\begin{array}{l}-0.017^{* * *} \\
(0.006)\end{array}$ & $\begin{array}{l}0.019^{*} \\
(0.010)\end{array}$ & $\begin{array}{l}-0.003 \\
(0.003)\end{array}$ & $\begin{array}{l}0.000 \\
(0.009)\end{array}$ \\
\hline House ownership, 2010 (yes $=1$ ) & $\begin{array}{l}-0.008 \\
(0.014)\end{array}$ & $\begin{array}{l}0.012 \\
(0.023)\end{array}$ & $\begin{array}{l}-0.004 \\
(0.010)\end{array}$ & $\begin{array}{l}0.000 \\
(0.019)\end{array}$ \\
\hline Constant & $\begin{array}{l}-0.062 \\
(0.051)\end{array}$ & $\begin{array}{l}1.095^{* * *} \\
(0.091)\end{array}$ & $\begin{array}{l}-0.042 \\
(0.044)\end{array}$ & $\begin{array}{l}0.009 \\
(0.079)\end{array}$ \\
\hline $\begin{array}{l}\text { Observations } \\
\text { Adjusted R-squared } \\
\text { PSU FE }\end{array}$ & $\begin{array}{l}3833 \\
0.148 \\
\text { Yes }\end{array}$ & $\begin{array}{l}3833 \\
0.335 \\
\text { Yes }\end{array}$ & $\begin{array}{l}3833 \\
0.144 \\
\text { Yes }\end{array}$ & $\begin{array}{l}3833 \\
0.309 \\
\text { Yes }\end{array}$ \\
\hline
\end{tabular}

Note: standard errors clustered at the PSU level are in parentheses

${ }^{*} p<0.1,{ }^{* *} p<0.05,{ }^{* * *} p<0.01$

at the one hand, the number of household members might reduce time of household chores and increase the chances of study and work, but at the other hand, these categories are affected by a larger number of younger children. Overall, children living in wealthier households at the time of the earthquake have better chances of study and do it for more hours and work less at home. 
Table 6 Fixed-effects model, number of hours

\begin{tabular}{|c|c|c|c|}
\hline & Hours studying & Hours working & Hours hh chores \\
\hline Household vulnerability index & $\begin{array}{l}-2.944^{*} \\
(1.736)\end{array}$ & $\begin{array}{l}1.007 \\
(0.806)\end{array}$ & $\begin{array}{l}3.745^{* * *} \\
(1.297)\end{array}$ \\
\hline Age & $\begin{array}{l}-0.136 \\
(0.119)\end{array}$ & $\begin{array}{l}0.233^{* * *} \\
(0.088)\end{array}$ & $\begin{array}{l}0.759 * * * \\
(0.117)\end{array}$ \\
\hline Sex $($ male $=1$ and at age $=13.55)$ & $\begin{array}{l}-0.205 \\
(0.287)\end{array}$ & $\begin{array}{l}1.164^{* * *} \\
(0.262)\end{array}$ & $\begin{array}{l}-4.492^{* * *} \\
(0.335)\end{array}$ \\
\hline Age ${ }^{*}$ sex & $\begin{array}{l}0.139 \\
(0.146)\end{array}$ & $\begin{array}{l}0.269^{* *} \\
(0.114)\end{array}$ & $\begin{array}{l}-0.700^{* * *} \\
(0.126)\end{array}$ \\
\hline Child's age order within the household & $\begin{array}{l}-0.355^{*} \\
(0.198)\end{array}$ & $\begin{array}{l}-0.231 \\
(0.151)\end{array}$ & $\begin{array}{l}-0.189 \\
(0.181)\end{array}$ \\
\hline Child was economically active, 2010 (yes $=1$ ) & $\begin{array}{l}-1.801^{* * *} \\
(0.686)\end{array}$ & $\begin{array}{l}9.521^{* * *} \\
(0.969)\end{array}$ & $\begin{array}{l}2.111^{* *} \\
(0.819)\end{array}$ \\
\hline Relation to head of household $=$ close relative $($ yes $=1$ ) & $\begin{array}{l}-1.024 \\
(0.654)\end{array}$ & $\begin{array}{l}0.059 \\
(0.487)\end{array}$ & $\begin{array}{l}-0.009 \\
(0.529)\end{array}$ \\
\hline Relation to head of household $=$ other relative (yes $=1$ ) & $\begin{array}{l}-1.446^{* * *} \\
(0.550)\end{array}$ & $\begin{array}{l}-0.377 \\
(0.359)\end{array}$ & $\begin{array}{l}1.379^{* * *} \\
(0.496)\end{array}$ \\
\hline Relation to head of household $=$ domestic employee $(y e s=1)$ & $\begin{array}{l}-2.823 \\
(1.867)\end{array}$ & $\begin{array}{l}0.632 \\
(1.655)\end{array}$ & $\begin{array}{l}7.261^{* * *} \\
(2.332)\end{array}$ \\
\hline Relation to head of household $=$ other relationship (yes $=1$ ) & $\begin{array}{l}-3.744^{* * * *} \\
(1.319)\end{array}$ & $\begin{array}{l}-0.052 \\
(1.205)\end{array}$ & $\begin{array}{l}2.698^{* *} \\
(1.356)\end{array}$ \\
\hline Sex of head of household $($ male $=1$ ) & $\begin{array}{l}0.720 \\
(0.564)\end{array}$ & $\begin{array}{l}0.250 \\
(0.343)\end{array}$ & $\begin{array}{l}0.598 \\
(0.428)\end{array}$ \\
\hline Head of household education level = primary $($ yes $=1$ ) & $\begin{array}{l}-0.470 \\
(0.507)\end{array}$ & $\begin{array}{l}0.231 \\
(0.367)\end{array}$ & $\begin{array}{l}-0.054 \\
(0.528)\end{array}$ \\
\hline Head of household education level = secondary or more $($ yes $=1)$ & $\begin{array}{l}0.398 \\
(0.855)\end{array}$ & $\begin{array}{l}0.575 \\
(0.399)\end{array}$ & $\begin{array}{l}0.147 \\
(0.598)\end{array}$ \\
\hline Live in the same house (yes $=1$ ) & $\begin{array}{l}-0.957 \\
(0.827)\end{array}$ & $\begin{array}{l}-0.013 \\
(0.488)\end{array}$ & $\begin{array}{l}0.606 \\
(0.637)\end{array}$ \\
\hline Household has received any type of assistance (yes $=1$ ) & $\begin{array}{l}-0.417 \\
(0.571)\end{array}$ & $\begin{array}{l}-0.121 \\
(0.394)\end{array}$ & $\begin{array}{l}0.337 \\
(0.481)\end{array}$ \\
\hline Number of negative economic shock & $\begin{array}{l}0.314 \\
(0.292)\end{array}$ & $\begin{array}{l}0.350^{* *} \\
(0.160)\end{array}$ & $\begin{array}{l}0.621^{* * *} \\
(0.205)\end{array}$ \\
\hline Members living in a temporary camp (\%) & $\begin{array}{l}6.474 \\
(6.045)\end{array}$ & $\begin{array}{l}4.073^{*} \\
(2.186)\end{array}$ & $\begin{array}{l}0.278 \\
(3.352)\end{array}$ \\
\hline Has any household member suffered physical damage (yes $=1$ ) & $\begin{array}{l}0.791 \\
(0.911)\end{array}$ & $\begin{array}{l}0.013 \\
(0.454)\end{array}$ & $\begin{array}{l}0.084 \\
(0.667)\end{array}$ \\
\hline Household size, 2010 & $\begin{array}{l}0.155 \\
(0.173)\end{array}$ & $\begin{array}{l}0.169 \\
(0.133)\end{array}$ & $\begin{array}{l}-0.303^{* *} \\
(0.152)\end{array}$ \\
\hline Number of children aged 0 to 10 years in household & $\begin{array}{l}-0.397 \\
(0.268)\end{array}$ & $\begin{array}{l}-0.181 \\
(0.160)\end{array}$ & $\begin{array}{l}0.398^{* *} \\
(0.201)\end{array}$ \\
\hline Durable assets index, 2010 & $\begin{array}{l}1.071 * * * \\
(0.404)\end{array}$ & $\begin{array}{l}-0.023 \\
(0.189)\end{array}$ & $\begin{array}{l}-0.426^{* *} \\
(0.201)\end{array}$ \\
\hline House ownership, 2010 (yes = 1) & $\begin{array}{l}-0.341 \\
(0.708)\end{array}$ & $\begin{array}{l}0.096 \\
(0.388)\end{array}$ & $\begin{array}{l}-0.099 \\
(0.503)\end{array}$ \\
\hline Constant & $\begin{array}{l}13.825^{* * *} \\
(2.152)\end{array}$ & $\begin{array}{l}-2.501 \\
(1.536)\end{array}$ & $\begin{array}{l}-0.708 \\
(2.019)\end{array}$ \\
\hline $\begin{array}{l}\text { Observations } \\
\text { Adjusted R-squared } \\
\text { PSU FE }\end{array}$ & $\begin{array}{l}3833 \\
0.512 \\
\text { Yes }\end{array}$ & $\begin{array}{l}3833 \\
0.287 \\
\text { Yes }\end{array}$ & $\begin{array}{l}3833 \\
0.272 \\
\text { Yes }\end{array}$ \\
\hline
\end{tabular}

Note: standard errors clustered at the PSU level are in parentheses ${ }^{*} p<0.1,{ }^{* *} p<0.05,{ }^{* * *} p<0.01$

Finally, we do not find any evidence that households receiving aid (assistance or having members living at refugee camps) is associated to the decision about the use of time of children. Living in 2012 at the same house where they live at the time of the earthquake, in contrast to living in a different house in the same community, is not associated to changes in investments in children's human capital. 


\section{Conclusions}

In January 2010, Haiti suffered a devastating earthquake that caused dramatic economic and personal losses. The total effect of the earthquake in people's lives happens through a natural factor (intensity), which is exogenous to people's behavior, and a vulnerability factor, which might be affected by the individual's behavior, and therefore potentially affected by policy. This paper examines the lasting effect of the household's vulnerability at the time of the earthquake on the decision about children's time allocation.

It is well known in the literature that investment in children's human capital has many positive effects on individuals' and countries' well-being. In fact, while natural hazards can affect a person's human capital throughout its entire life, it is at the early stages in life when any such impacts most matter if they are not properly and timely addressed. Our results show that this is at risk for Haiti. The household's vulnerability, as with many other children's characteristics, is associated with larger chances of working and lower chances of studying for children that are at school age. These results support us to affirm that social policies should focus on reducing households' vulnerability and other observable characteristics that might reduce investments in children's human capital.

This paper uses a rich and original dataset including information about the earthquake's intensity and damage, children's answers about the use of their time, time devoted to domestic and market work, and characteristics of individuals and households before the 2010 earthquake happened. Despite the richness of our data, we are not able to disentangle whether the household decision about children's time reflects the household or child unobserved characteristics (e.g., household's preferences for schooling and child labor, child's depression, stress, or ability to take advantage of school). However, the importance of the research question from a policy point of view and the lack of empirical evidence for Haiti makes the analysis relevant.

We believe that the results of this research are of interest beyond Haiti, as key features of the Haitian system-low state capacity and historical lack of welldeveloped and functioning system of public schools-are common to many low-income countries, while the rapid growth of nonpublic schools in many of these countries makes the Haitian case, with a large and vibrant nonpublic sector, increasingly relevant.

The sample used in this paper is restricted to survivors of the 2010 earthquake, and therefore, our results can be interpreted as lower bound estimates of the real effect of vulnerability at the time of the earthquake on investments in children's human capital. This is potentially reinforced by restricting our sample to only children who did not change household and did not move to another geographical area.

\section{Endnotes}

${ }^{1}$ Birkmann (2013) provides an extended review of the different frameworks, techniques, and methodologies for assessing and measuring vulnerability at different levels and with different thematic focuses.

${ }^{2}$ Human Development Index of the United Nations Development Programme https://data.undp.org/dataset/Human-Development-Index-HDI-value/8ruz-shxu

${ }^{3}$ ECVMAS was conducted by the Haitian Institute of Statistics (IHSI) as part of a program supported by the French National Research Agency (ANR), DIAL Research Unit, and the World Bank. The methodology was a variation on the 1-2-3 Survey, developed 
by DIAL to measure the informal economy and poverty. Javier Herrera, IRD Research Director, was the ANR project manager and Claire Zanuso was the ANR project coordinator from 2011 to 2014 and survey coordinator in Haiti. All data in this paper are from ECVMAS 2012, unless otherwise indicated.

${ }^{4}$ These criteria are imposed to avoid the possibility of unobserved variables related to changes in household composition biasing our estimates. At applying them, we exclude less than $10 \%$ of children on this age group. Another source of sample selection bias is only having data of children who survived the earthquake. If surviving is not orthogonal to the household's vulnerability, we should expect that our results are lower estimates of the real effect.

${ }^{5}$ Unfortunately, even doing this, we are not able to account for some child's or household's characteristics that might determine schooling and working (e.g., school readiness).

${ }^{6}$ The construct of flashbulb memory was introduced in a seminal paper by (Brown and Kulik 1977) to account for memories of events such as the assassination of John F. Kennedy.

${ }^{7}$ Baez et al. (2010) offers a recent and synthetic review on consumption, nutrition, and health dimensions.

${ }^{8}$ Likely due to lack of suitable data, few studies address the impact of high-magnitude earthquakes. For instance, see Doocy et al. (2013) for a review; Yang (2008) for China; and Halliday (2006) for El Savador. Torche (2011) disentangles the impact of the maternal stress on birth outcomes exploiting the 2005 earthquake in Chile as a natural experiment.

${ }^{9}$ Based on available population projections of the Haitian Institute of Statistics and Informatics (IHSI), 2012.

${ }^{10}$ See Lamaute-Brisson (2013); Lamaute-Brisson (2015) for a more exhaustive and historical view of social protection systems in Haiti.

${ }^{11}$ The geographic divisions of Haiti are 10 departments, 41 districts, 133 communes, and 565 sections within the communes. The country can also be divided into 11,967 primary sampling units (PSUs), the smallest statistical division. The ECVMAS sample counts 500 PSUs, including 30 PSUs in refugee camps.

${ }^{12}$ This information is consistent with the "color-code" damage classification of the Ministry of Public Works Transport and Communications (MTPTC). Between February 2010 and 2011, MTPTC, with the support of USAID, assessed the habitability and color-coded 382,246 buildings according to the level of damages. Green-tagged buildings were structurally evaluated as safe, the yellow-tagged ones were unsafe to inhabit but reparable, and red-tagged buildings as unsafe to enter or damaged beyond repair. The MTPTC's evaluation followed the ATC-20 (ATC 1987) rapid assessment methodology, which has been successfully used for evaluation after major earthquakes in the USA, with adaptations to Haitian construction practices. We are able to check the consistency between our indicator of damage score and the one of MTPTC for $40 \%$ of ECVMAS sample. The remaining corresponds to buildings located outside Port-au-Prince and rubble buildings, which were not evaluated by MTPTC, and households who were no longer living in the dwelling where they lived at the time of the earthquake. Among households in which comparison of the two indicators is possible, $92 \%$ of those who declared none-slight damage on their dwelling were tagged as green, $90 \%$ of those who declared light-moderate damage were tagged as green and yellow, and $86 \%$ of those who declared a destroyed 
damage were consistently red-tagged. Only $15 \%$ of those who declared heavy-major damage and $10 \%$ of those who declared destroyed damage were not consistent with the MTPTC classification.

${ }^{13}$ The questions related to household chores correspond to time devoted to the following: cleaning, cooking, taking care of other household member, reconstruction or construction of their own houses, fetching water or wood, and going to the market to buy goods for their households.

${ }^{14}$ For each 500 PSUs in the ECVMAS sample, 16 households were randomly selected in the metropolitan area of Port-au-Prince and in the refugee camps and 8 households for the rest of the country.

${ }^{15}$ In the absence of seismographic stations across the country, PGA is calculated imputing data from earthquakes' characteristics and geography of impacted areas, based on attenuation relations created by seismologists and engineers. In the specific case of Haiti, even if the PGA is a more complete measure of earthquake intensity than the distance to the epicenter, it is not a perfect measure of it. Eberhard et al. (2010) mentions that the lack of seismographs and detailed knowledge of the physical conditions of the soils (e.g., lithology, stiffness, density, thickness) limit the precision of USGS assessment of ground motion amplification in the widespread damage.

${ }^{16}$ This assistance includes the information campaign aimed at preventing cholera epidemic. The incidence is significantly lower when it comes to assistance other than information campaigns. The long-term economic assistance concerned a small proportion of the impacted population (Herrera et al. 2014)

${ }^{17} v$ might also include measurement error. For instance, if, as indicated, the accuracy of an individual's memory is affected by the intensity of the earthquake, $v$ would be systematically different, in an unpredictable way, for those less hit. As it is not either possible to a priori give a sign to the effect of the potential measurement error, we are not able to say whether our estimates of vulnerability represent a lower or an upper bound of the real effect. This reflects in the fact that our results should be taken as conditional associations rather than causal effects.

${ }^{18}$ Table 2 and Fig. 2 in the Appendix show the OLS estimate of Eq. 1 and the distribution of the vulnerability index, respectively.

${ }^{19}$ As Tables 9 and 10 in the Appendix show, not including PSU FE does not change much the magnitude and significance in all relevant covariates, which suggests that not including them in our MNL and SUR models would not alter the reported estimates. Moreover, using an OLS or a logit model yields to similar estimates in magnitude and significance (Table 11 in the Appendix).

${ }^{20}$ Selection of children into each activity (studying, working, etc.) is likely not to be random. In fact, all specifications dealing with participation into each activity along the paper suggest what characteristics are associated with participation. However, we unfortunately do not count with a valid exclusion restriction for modeling this selection (à la Heckman). To partially account for this issue, our specifications control for a large set of observed characteristics that is likely to affect both the selection into the activity and the number of hours on that activity. Still, this does not count for selection driven by unobserved characteristics, and therefore, our results should be taken as conditional associations rather than causal effects. 


\section{Appendix}

Table 7 Haitian education system

\begin{tabular}{llll}
\hline 19 years and above & & & Superior \\
\hline 18 years & Final year-Philo & Secondary \\
17 years & 1 st year-Rheto & \\
16 years & 2 nd year & \\
15 years & 3rd year & \\
\hline 14 years & 9 stAF & 3rd cycle & \\
13 years & 8 stAF & & \\
12 years & 7 stAF & 2nd cycle & \\
\hline 11 years & 6 stAF & \\
10 years & 5 stAF & Primary \\
\hline 9 years & 4 stAF & \\
8 years & 3 rdAF & \\
7 years & 2 ndAF & \\
6 years & 1 st AF & & \\
\hline 5 years & Upper & \\
4 years & Middle & \\
3 years & Lower & \\
\hline
\end{tabular}

Table 8 Asset ownership and weights obtained from MCA

\begin{tabular}{|c|c|c|c|c|}
\hline Assets & Ownership & \% Households (2010) & \% Households (2012) & Weights \\
\hline Oven & $\begin{array}{l}0 \\
1\end{array}$ & $\begin{array}{l}94.35 \\
5.65\end{array}$ & $\begin{array}{l}94.56 \\
5.44\end{array}$ & $\begin{array}{l}-0.28 \\
5.03\end{array}$ \\
\hline Television & $\begin{array}{l}0 \\
1\end{array}$ & $\begin{array}{l}71.7 \\
28.3\end{array}$ & $\begin{array}{l}71.8 \\
28.2\end{array}$ & $\begin{array}{l}-0.75 \\
2.01\end{array}$ \\
\hline Radio & $\begin{array}{l}0 \\
1\end{array}$ & $\begin{array}{l}55.96 \\
44.04\end{array}$ & $\begin{array}{l}57.99 \\
42.01\end{array}$ & $\begin{array}{l}-0.69 \\
0.88\end{array}$ \\
\hline Mobile phone & $\begin{array}{l}0 \\
1\end{array}$ & $\begin{array}{l}40.07 \\
59.93\end{array}$ & $\begin{array}{l}24.42 \\
75.58\end{array}$ & $\begin{array}{l}-1.04 \\
0.56\end{array}$ \\
\hline Fridge & $\begin{array}{l}0 \\
1\end{array}$ & $\begin{array}{l}90.68 \\
9.32\end{array}$ & $\begin{array}{l}91.24 \\
8.76\end{array}$ & $\begin{array}{l}-0.41 \\
4.16\end{array}$ \\
\hline Generator & $\begin{array}{l}0 \\
1\end{array}$ & $\begin{array}{l}98.07 \\
1.93\end{array}$ & $\begin{array}{l}97.75 \\
2.25\end{array}$ & $\begin{array}{l}-0.15 \\
6.16\end{array}$ \\
\hline Inverter & $\begin{array}{l}0 \\
1\end{array}$ & $\begin{array}{l}96.42 \\
3.58\end{array}$ & $\begin{array}{l}96.58 \\
3.42\end{array}$ & $\begin{array}{l}-0.22 \\
5.53\end{array}$ \\
\hline Computer & $\begin{array}{l}0 \\
1\end{array}$ & $\begin{array}{l}97.16 \\
2.84\end{array}$ & $\begin{array}{l}96.09 \\
3.91\end{array}$ & $\begin{array}{l}-0.19 \\
6.16\end{array}$ \\
\hline Ventilator & $\begin{array}{l}0 \\
1\end{array}$ & $\begin{array}{l}86.46 \\
13.54\end{array}$ & $\begin{array}{l}86.95 \\
13.05\end{array}$ & $\begin{array}{l}-0.49 \\
3.09\end{array}$ \\
\hline Car & $\begin{array}{l}0 \\
1\end{array}$ & $\begin{array}{l}97.23 \\
2.77\end{array}$ & $\begin{array}{l}97.18 \\
2.82\end{array}$ & $\begin{array}{l}-0.20 \\
6.03\end{array}$ \\
\hline Motorcycle & $\begin{array}{l}0 \\
1\end{array}$ & $\begin{array}{l}96.32 \\
3.68\end{array}$ & $\begin{array}{l}95.26 \\
4.74\end{array}$ & $\begin{array}{l}-0.06 \\
1.55\end{array}$ \\
\hline Sewing machine & $\begin{array}{l}0 \\
1\end{array}$ & $\begin{array}{l}96.93 \\
3.07\end{array}$ & $\begin{array}{l}96.96 \\
3.04\end{array}$ & $\begin{array}{l}-0.06 \\
1.59\end{array}$ \\
\hline
\end{tabular}


Table 9 OLS model without FE, school/work decision

\begin{tabular}{|c|c|c|c|c|}
\hline & Idle & $\begin{array}{l}\text { School } \\
\text { only }\end{array}$ & $\begin{array}{l}\text { Work } \\
\text { only }\end{array}$ & $\begin{array}{l}\text { School and } \\
\text { work }\end{array}$ \\
\hline Household vulnerability index & $\begin{array}{l}0.044 \\
(0.028)\end{array}$ & $\begin{array}{l}-0.112^{* *} \\
(0.054)\end{array}$ & $\begin{array}{l}0.049^{* *} \\
(0.021)\end{array}$ & $\begin{array}{l}0.018 \\
(0.049)\end{array}$ \\
\hline Age & $\begin{array}{l}0.011^{* * *} \\
(0.003)\end{array}$ & $\begin{array}{l}-0.015^{* * *} \\
(0.005)\end{array}$ & $\begin{array}{l}*^{0} 0.001 \\
(0.002)\end{array}$ & $\begin{array}{l}0.003 \\
(0.004)\end{array}$ \\
\hline Sex $($ male $=1$ and at age $=13.55)$ & $\begin{array}{l}-0.032^{* * *} \\
(0.008)\end{array}$ & $\begin{array}{l}-0.032^{* *} \\
(0.014)\end{array}$ & $\begin{array}{l}0.015^{* * *} \\
(0.006)\end{array}$ & $\begin{array}{l}0.049^{* * *} \\
(0.013)\end{array}$ \\
\hline Age ${ }^{*}$ sex & $\begin{array}{l}-0.009^{* *} \\
(0.004)\end{array}$ & $\begin{array}{l}-0.002 \\
(0.006)\end{array}$ & $\begin{array}{l}0.002 \\
(0.003)\end{array}$ & $\begin{array}{l}0.009^{*} \\
(0.005)\end{array}$ \\
\hline Child's age order within the household & $\begin{array}{l}0.012^{* *} \\
(0.005)\end{array}$ & $\begin{array}{l}0.016^{*} \\
(0.008)\end{array}$ & $\begin{array}{l}-0.002 \\
(0.004)\end{array}$ & $\begin{array}{l}-0.026^{* * *} \\
(0.007)\end{array}$ \\
\hline Child was economically active, 2010 (yes = 1) & $\begin{array}{l}-0.008 \\
(0.015)\end{array}$ & $\begin{array}{l}-0.525^{* * *} \\
(0.027)\end{array}$ & $\begin{array}{l}{ }^{*} 0.140^{* * *} \\
(0.025)\end{array}$ & $\begin{array}{l}0.393^{* * *} \\
(0.035)\end{array}$ \\
\hline Relation to head of household = close relative (yes $=1$ ) & $\begin{array}{l}0.030^{* *} \\
(0.015)\end{array}$ & $\begin{array}{l}0.001 \\
(0.024)\end{array}$ & $\begin{array}{l}-0.011 \\
(0.009)\end{array}$ & $\begin{array}{l}-0.020 \\
(0.022)\end{array}$ \\
\hline Relation to head of household = other relative (yes $=1$ ) & $\begin{array}{l}0.036^{* * *} \\
(0.014)\end{array}$ & $\begin{array}{l}0.011 \\
(0.021)\end{array}$ & $\begin{array}{l}0.011 \\
(0.008)\end{array}$ & $\begin{array}{l}-0.057^{* * *} \\
(0.018)\end{array}$ \\
\hline Relation to head of household = domestic employee $($ yes $=1$ ) & $\begin{array}{l}0.073 \\
(0.057)\end{array}$ & $\begin{array}{l}-0.162^{* *} \\
(0.072)\end{array}$ & $\begin{array}{l}0.051 \\
(0.047)\end{array}$ & $\begin{array}{l}0.038 \\
(0.064)\end{array}$ \\
\hline Relation to head of household = other relationship (yes $=1$ ) & $\begin{array}{l}0.014 \\
(0.035)\end{array}$ & $\begin{array}{l}-0.053 \\
(0.064)\end{array}$ & $\begin{array}{l}0.042 \\
(0.032)\end{array}$ & $\begin{array}{l}-0.003 \\
(0.058)\end{array}$ \\
\hline Sex of head of household $($ male $=1$ ) & $\begin{array}{l}-0.009 \\
(0.011)\end{array}$ & $\begin{array}{l}-0.075^{* * *} \\
(0.018)\end{array}$ & $\begin{array}{l}* 0.010 \\
(0.008)\end{array}$ & $\begin{array}{l}0.075^{* * *} \\
(0.015)\end{array}$ \\
\hline Head of household education level = primary (yes $=1$ ) & $\begin{array}{l}-0.016 \\
(0.013)\end{array}$ & $\begin{array}{l}0.061^{* * *} \\
(0.021)\end{array}$ & $\begin{array}{l}-0.019 * * \\
(0.009)\end{array}$ & $\begin{array}{l}-0.026 \\
(0.018)\end{array}$ \\
\hline Head of household education level = secondary or more (yes $=1$ ) & $\begin{array}{l}-0.048^{* * *} \\
(0.012)\end{array}$ & $\begin{array}{l}0.116^{* * *} \\
(0.022)\end{array}$ & $\begin{array}{l}-0.036^{* * *} \\
(0.007)\end{array}$ & $\begin{array}{l}{ }^{*}-0.032 \\
(0.020)\end{array}$ \\
\hline Live in the same house (yes $=1$ ) & $\begin{array}{l}0.015 \\
(0.012)\end{array}$ & $\begin{array}{l}-0.012 \\
(0.025)\end{array}$ & $\begin{array}{l}0.001 \\
(0.011)\end{array}$ & $\begin{array}{l}-0.003 \\
(0.024)\end{array}$ \\
\hline Household has received any type of assistance (yes $=1$ ) & $\begin{array}{l}-0.023^{* *} \\
(0.011)\end{array}$ & $\begin{array}{l}0.011 \\
(0.020)\end{array}$ & $\begin{array}{l}0.000 \\
(0.007)\end{array}$ & $\begin{array}{l}0.012 \\
(0.018)\end{array}$ \\
\hline Number of negative economic shock & $\begin{array}{l}-0.008 \\
(0.005)\end{array}$ & $\begin{array}{l}-0.027^{* * *} \\
(0.009)\end{array}$ & $\begin{array}{l}{ }^{*} 0.005^{* *} \\
(0.003)\end{array}$ & $\begin{array}{l}0.030^{* * *} \\
(0.007)\end{array}$ \\
\hline Members living in a temporary camp (\%) & $\begin{array}{l}0.022 \\
(0.023)\end{array}$ & $\begin{array}{l}0.048 \\
(0.040)\end{array}$ & $\begin{array}{l}-0.003 \\
(0.016)\end{array}$ & $\begin{array}{l}-0.067^{* *} \\
(0.034)\end{array}$ \\
\hline Has any household member suffered physical damage $($ yes $=1$ ) & $\begin{array}{l}-0.013 \\
(0.014)\end{array}$ & $\begin{array}{l}0.032 \\
(0.027)\end{array}$ & $\begin{array}{l}0.004 \\
(0.009)\end{array}$ & $\begin{array}{l}-0.023 \\
(0.024)\end{array}$ \\
\hline Household size, 2010 & $\begin{array}{l}-0.012^{* * *} \\
(0.004)\end{array}$ & $\begin{array}{l}-0.010 \\
(0.007)\end{array}$ & $\begin{array}{l}-0.002 \\
(0.003)\end{array}$ & $\begin{array}{l}0.024^{* * *} \\
(0.007)\end{array}$ \\
\hline Number of children aged 0 to 10 years in household & $\begin{array}{l}0.017^{* * *} \\
(0.006)\end{array}$ & $\begin{array}{l}0.003 \\
(0.009)\end{array}$ & $\begin{array}{l}0.003 \\
(0.004)\end{array}$ & $\begin{array}{l}-0.022^{* * *} \\
(0.009)\end{array}$ \\
\hline Durable assets index, 2010 & $\begin{array}{l}-0.016^{* * *} \\
(0.004)\end{array}$ & $\begin{array}{l}0.043^{* * *} \\
(0.009)\end{array}$ & $\begin{array}{l}-0.003 \\
(0.003)\end{array}$ & $\begin{array}{l}-0.024^{* * *} \\
(0.007)\end{array}$ \\
\hline House ownership, 2010 (yes $=1$ ) & $\begin{array}{l}-0.018 \\
(0.012)\end{array}$ & $\begin{array}{l}-0.048^{* *} \\
(0.019)\end{array}$ & $\begin{array}{l}0.009 \\
(0.008)\end{array}$ & $\begin{array}{l}0.056^{* * *} \\
(0.016)\end{array}$ \\
\hline Constant & $\begin{array}{l}0.116^{* * *} \\
(0.028)\end{array}$ & $\begin{array}{l}0.878^{* * * *} \\
(0.048)\end{array}$ & $\begin{array}{l}0.003 \\
(0.016)\end{array}$ & $\begin{array}{l}0.002 \\
(0.042)\end{array}$ \\
\hline $\begin{array}{l}\text { Observations } \\
\text { R-squared } \\
\text { PSU FE }\end{array}$ & $\begin{array}{l}3833 \\
0.034 \\
\text { No }\end{array}$ & $\begin{array}{l}3833 \\
0.184 \\
\text { No }\end{array}$ & $\begin{array}{l}3833 \\
0.068 \\
\text { No }\end{array}$ & $\begin{array}{l}3833 \\
0.148 \\
\text { No }\end{array}$ \\
\hline
\end{tabular}

Note: standard errors clustered at the PSU level are in parentheses ${ }^{*} p<0.1,{ }^{* *} p<0.05,{ }^{* * *} p<0.01$ 
Table 10 OLS model without FE, number of hours

\begin{tabular}{|c|c|c|c|}
\hline & Hours studying & Hours working & Hours hh chores \\
\hline Household vulnerability index & $\begin{array}{l}-3.556^{* *} \\
(1.721)\end{array}$ & $\begin{array}{l}1.204 \\
(0.775)\end{array}$ & $\begin{array}{l}4.945^{* * *} \\
(1.295)\end{array}$ \\
\hline Age & $\begin{array}{l}-0.122 \\
(0.126)\end{array}$ & $\begin{array}{l}0.144^{*} \\
(0.074)\end{array}$ & $\begin{array}{l}0.669^{* * *} \\
(0.112)\end{array}$ \\
\hline Sex $($ male $=1$ and at age $=13.55)$ & $\begin{array}{l}-0.512 \\
(0.351)\end{array}$ & $\begin{array}{l}1.213^{* * *} \\
(0.252)\end{array}$ & $\begin{array}{l}-4.212^{* * *} \\
(0.307)\end{array}$ \\
\hline Age $^{*} \operatorname{sex}$ & $\begin{array}{l}0.206 \\
(0.164)\end{array}$ & $\begin{array}{l}0.233^{* *} \\
(0.108)\end{array}$ & $\begin{array}{l}-0.756^{* * *} \\
(0.122)\end{array}$ \\
\hline Child's age order within the household & $\begin{array}{l}-0.146 \\
(0.204)\end{array}$ & $\begin{array}{l}-0.477^{* * *} \\
(0.132)\end{array}$ & $\begin{array}{l}-0.473^{* * *} \\
(0.173)\end{array}$ \\
\hline \multirow{2}{*}{$\begin{array}{l}\text { Child was economically active, } 2010 \text { (yes = } \\
\text { 1) }\end{array}$} & $-3.939^{* * *}$ & $10.288^{* * *}$ & $2.078^{* * *}$ \\
\hline & $(0.682)$ & $(0.875)$ & $(0.723)$ \\
\hline \multirow{2}{*}{$\begin{array}{l}\text { Relation to head of household }=\text { close } \\
\text { relative (yes }=1 \text { ) }\end{array}$} & $-1.270^{*}$ & -0.214 & -0.112 \\
\hline & $(0.646)$ & $(0.418)$ & $(0.489)$ \\
\hline \multirow{2}{*}{$\begin{array}{l}\text { Relation to head of household }=\text { other } \\
\text { relative (yes }=1 \text { ) }\end{array}$} & $-1.094^{*}$ & $-0.559^{*}$ & $1.310^{* * *}$ \\
\hline & $(0.606)$ & $(0.334)$ & $(0.443)$ \\
\hline \multirow{2}{*}{$\begin{array}{l}\text { Relation to head of household = domestic } \\
\text { employee }(\text { yes }=1 \text { ) }\end{array}$} & $-6.673^{* * *}$ & 2.032 & $7.882^{* * *}$ \\
\hline & $(1.886)$ & $(1.588)$ & $(2.494)$ \\
\hline \multirow{2}{*}{$\begin{array}{l}\text { Relation to head of household = other } \\
\text { relationship (yes }=1 \text { ) }\end{array}$} & $-4.657^{* * *}$ & 0.623 & 2.001 \\
\hline & $(1.732)$ & $(0.991)$ & $(1.241)$ \\
\hline Sex of head of household (male $=1$ ) & $\begin{array}{l}-0.742 \\
(0.585)\end{array}$ & $\begin{array}{l}1.107^{* * *} \\
(0.273)\end{array}$ & $\begin{array}{l}1.303^{* * *} \\
(0.377)\end{array}$ \\
\hline \multirow{2}{*}{$\begin{array}{l}\text { Head of household education level = pri- } \\
\text { mary (yes }=1 \text { ) }\end{array}$} & 0.769 & -0.450 & -0.299 \\
\hline & $(0.553)$ & $(0.315)$ & $(0.438)$ \\
\hline \multirow{2}{*}{$\begin{array}{l}\text { Head of household education level = sec- } \\
\text { ondary or more (yes }=1 \text { ) }\end{array}$} & $3.825^{* * *}$ & $-0.733^{* *}$ & $-1.225^{* *}$ \\
\hline & $(0.897)$ & $(0.329)$ & $(0.515)$ \\
\hline Live in the same house (yes $=1$ ) & $\begin{array}{l}-1.244 \\
(0.879)\end{array}$ & $\begin{array}{l}0.025 \\
(0.410)\end{array}$ & $\begin{array}{l}0.538 \\
(0.607)\end{array}$ \\
\hline \multirow{2}{*}{$\begin{array}{l}\text { Household has received any type of assis- } \\
\text { tance (yes }=1 \text { ) }\end{array}$} & -0.162 & -0.199 & -0.427 \\
\hline & $(0.651)$ & $(0.305)$ & $(0.389)$ \\
\hline Number of negative economic shock & $\begin{array}{l}-0.224 \\
(0.298)\end{array}$ & $\begin{array}{l}0.552^{* * *} \\
(0.125)\end{array}$ & $\begin{array}{l}1.174^{* * *} \\
(0.171)\end{array}$ \\
\hline Members living in a temporary camp (\%) & $\begin{array}{l}4.992^{* * *} \\
(1.725)\end{array}$ & $\begin{array}{l}-0.276 \\
(0.761)\end{array}$ & $\begin{array}{l}-1.991^{* *} \\
(0.900)\end{array}$ \\
\hline \multirow{2}{*}{$\begin{array}{l}\text { Has any household member suffered } \\
\text { physical damage (yes }=1 \text { ) }\end{array}$} & $2.856^{* * *}$ & -0.457 & 0.091 \\
\hline & $(0.893)$ & $(0.409)$ & $(0.580)$ \\
\hline Household size, 2010 & $\begin{array}{l}-0.314^{*} \\
(0.178)\end{array}$ & $\begin{array}{l}0.382^{* * *} \\
(0.140)\end{array}$ & $\begin{array}{l}-0.119 \\
(0.134)\end{array}$ \\
\hline \multirow{2}{*}{$\begin{array}{l}\text { Number of children aged } 0 \text { to } 10 \text { years in } \\
\text { household }\end{array}$} & -0.328 & $-0.311^{*}$ & $0.292^{*}$ \\
\hline & $(0.255)$ & $(0.171)$ & $(0.168)$ \\
\hline Durable assets index, 2010 & $\begin{array}{l}2.731^{* * *} \\
(0.394)\end{array}$ & $\begin{array}{l}-0.270 \\
(0.191)\end{array}$ & $\begin{array}{l}-0.938^{* * *} \\
(0.165)\end{array}$ \\
\hline House ownership, 2010 (yes = 1) & $\begin{array}{l}-2.645^{* * *} \\
(0.761)\end{array}$ & $\begin{array}{l}1.067^{* * *} \\
(0.283)\end{array}$ & $\begin{array}{l}1.025^{* *} \\
(0.449)\end{array}$ \\
\hline Constant & $\begin{array}{l}16.794^{* * *} \\
(1.452)\end{array}$ & $\begin{array}{l}-0.269 \\
(0.692)\end{array}$ & $\begin{array}{l}8.084^{* * *} \\
(1.047)\end{array}$ \\
\hline $\begin{array}{l}\text { Observations } \\
\text { Adjusted R-squared } \\
\text { PSU FE }\end{array}$ & $\begin{array}{l}3833 \\
0.171 \\
\text { No }\end{array}$ & $\begin{array}{l}3833 \\
0.188 \\
\text { No }\end{array}$ & $\begin{array}{l}3833 \\
0.143 \\
\text { No }\end{array}$ \\
\hline
\end{tabular}

Note: standard errors clustered at the PSU level are in parentheses ${ }^{*} p<0.1,{ }^{* *} p<0.05,{ }^{* * *} p<0.01$ 
Table 11 Logit model without FE, school/work decision

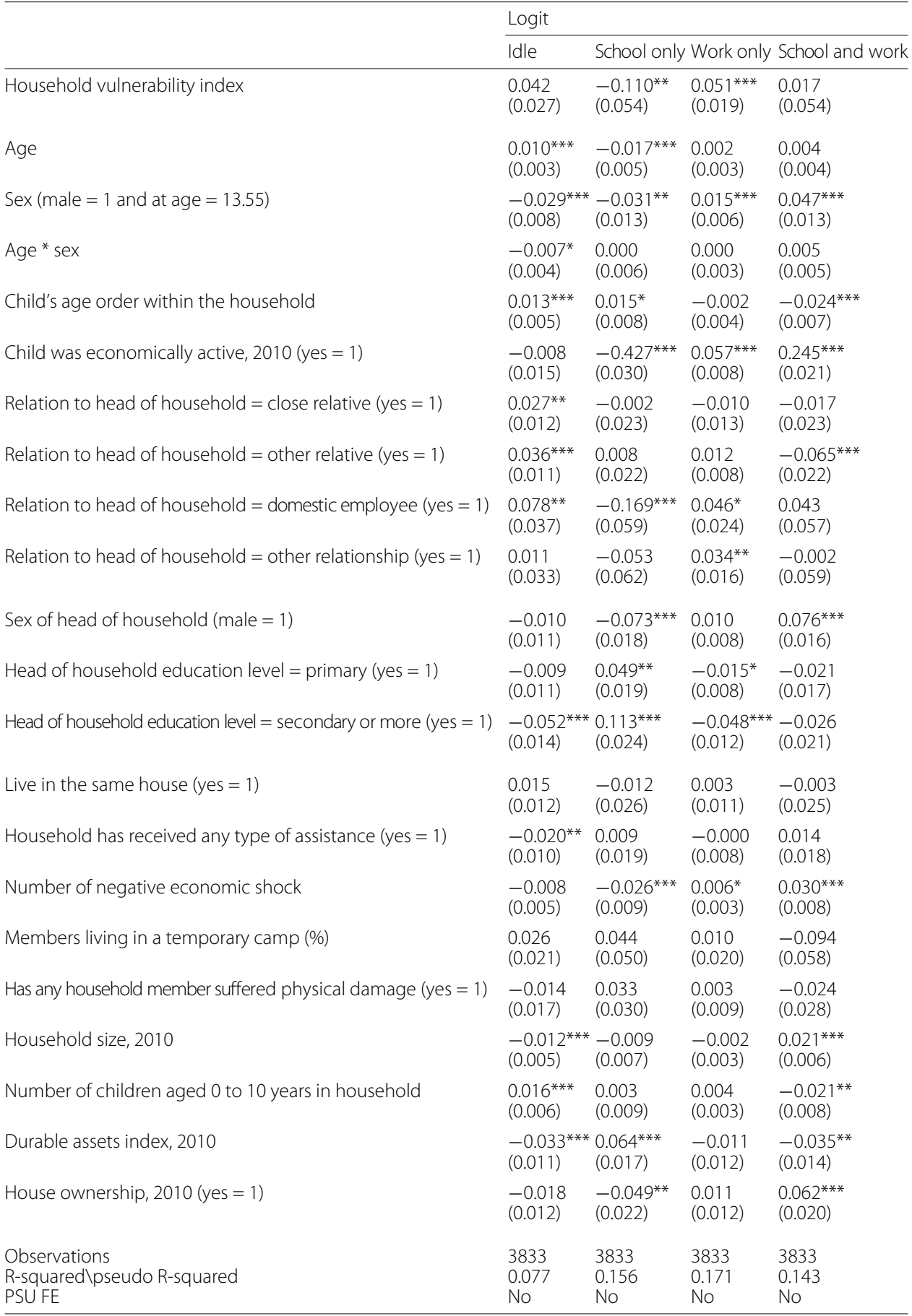

Note: results are marginal effects. Standard errors clustered at the PSU level are in parentheses ${ }^{*} p<0.1,{ }^{* *} p<0.05,{ }^{* * *} p<0.01$ 


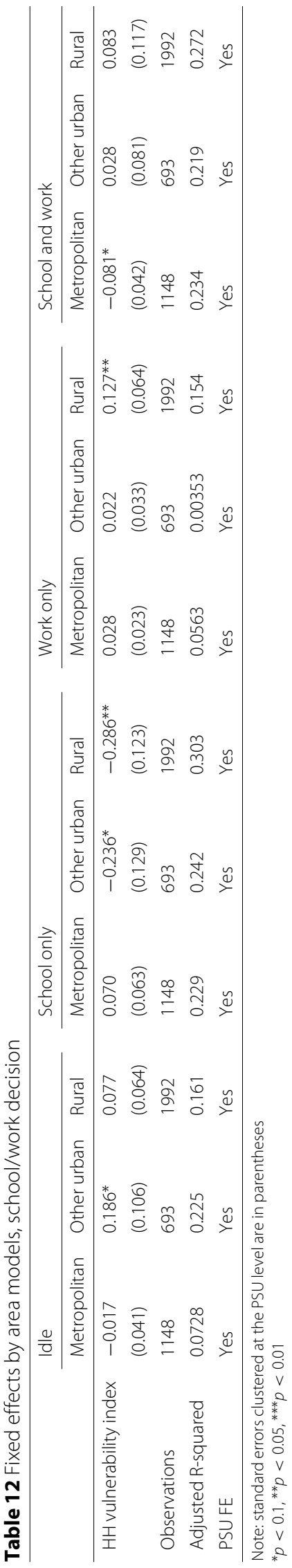




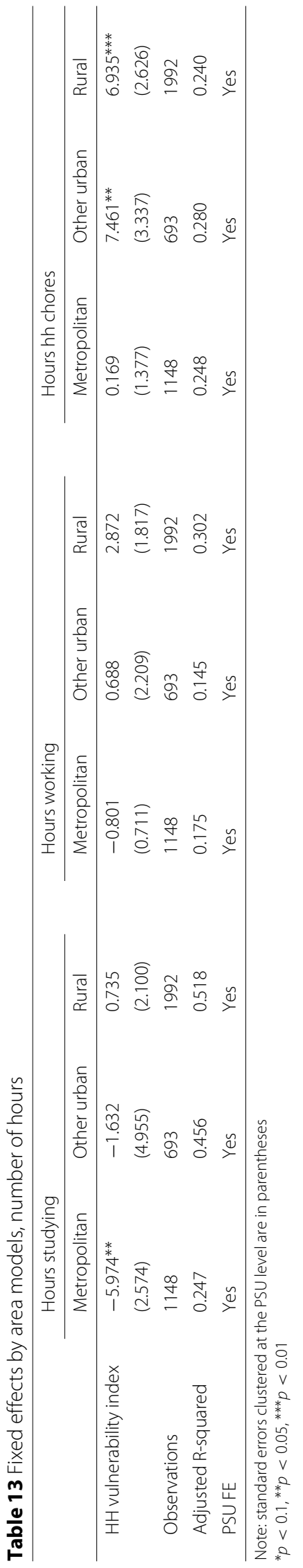




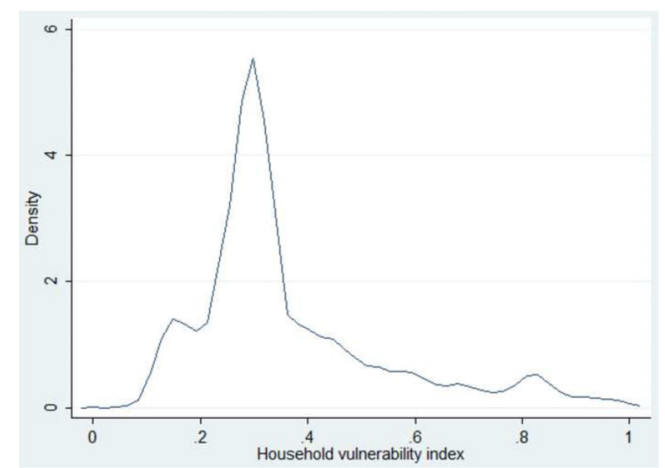

Fig. 2 Kernel density household vulnerability index

\section{Acknowledgements}

We would like to thank participants at the 4th SOLE/EALE World Conference; the 3rd Dial Conference "Barriers to Development"; the IZA Workshop: "Which Institutions Promote Youth Employment?"; the 4th LACEA Labor Network conference "Are labor markets in Latin America prepared for the new challenges?"; and the 2015 Warwick PhD conference for their helpful suggestions. We would also like to thank the anonymous referee and the editor for the useful comments. Responsible editor: David Lam

\section{Funding}

There are no sources of funding for the research that need to be declared for this paper. The authors declare that they have no conflict of interest.

\section{Competing interests}

The IZA Journal of Development and Migration is committed to the IZA Guiding Principles of Research Integrity. The authors declare that they have observed these principles.

\section{Publisher's Note}

Springer Nature remains neutral with regard to jurisdictional claims in published maps and institutional affiliations.

\section{Author details}

${ }^{1}$ Inter-American Development Bank, IDB Headquarters 1300 New York Avenue, 20577 N.W. Washington, D.C., USA.

${ }^{2}$ Agence Française de Développement (AFD), 5 rue Roland Barthes, 75012 Paris, France. ${ }^{3}$ DIAL, Université Paris-Dauphine,

4, rue d'Enghien, 75010 Paris, France.

Received: 3 July 2017 Accepted: 5 July 2017

Published online: 21 February 2018

References

Adelman MA, Holland PA. Increasing access by waiving tuition: evidence from Haiti, World Bank Policy Research Working Paper 7175 (7175). 2015.

Alderman H, Hoddinott J, Kinsey B. Long term consequences of early childhood malnutrition. Oxf Econ Pap. 2006;58(3): 450-74.

Asselin L-M. Analysis of multidimensional poverty: theory and case studies, Vol. 7. London: Springer Science \& Business Media; 2009.

Asselin L-M, Anh VT. Multidimensional poverty and multiple correspondence analysis. In: Kakwani N, Silber J, editors. Quantitative Approaches to Multidimensional Poverty Measurement. London: Palgrave Macmillan; 2008. p. 80-103.

ATC. Evaluating the seismic resistance of existing buildings, ATC-14 Report, Technical report. Redwood City: Advanced Technology Council; 1987.

Baez J, De la Fuente A, Santos IV. Do natural disasters affect human capital? An assessment based on existing empirical evidence. IZA Discussion Paper No. 5164. 2010.

Baez JE, Santos IV. Children's vulnerability to weather shocks: a natural disaster as a natural experiment. Soc Sci Res Netw New York. 2007. (mimeo).

Baland J-M, Robinson JA. Is child labor inefficient? J Polit Econ. 2000;108(4):663-79.

Basu K, Das S, Dutta B. Child labor and household wealth: theory and empirical evidence of an inverted-U. J Dev Econ. 2010;91(1):8-14.

Basu, K, Van PH. The economics of child labor. Am Econ Rev. 1998;88:412-27.

Basu K, Van PH. The economics of child labor: reply. Am Econ Rev. 1999;89:1386-8.

Becker GS. Human Capital: A theoretical and empirical analysis, with special reference to education. National Bureau of Economic Research; 1964

Beegle K, Dehejia R, Gatti R. Child labor, crop shocks, and credit constraints: National Bureau of Economic Research, Working paper No. 10088; 2003 . 
Beegle K, Dehejia RH, Gatti R. Do households resort to child labor to cope with income shocks? National Bureau of Economic Research, Working paper No. 9018; 2002.

Benzecri J-P, et al. L'analyse des données, Tome 2. Paris: Dunod; 1973

Bhalotra S. Is child work necessary? Oxford Bull Econ Stat. 2007;69(1):29-55.

Bhalotra S, Heady C. Child farm labor: the wealth paradox. World Bank Econ Rev. 2003;17(2):197-227.

Biggeri M, Guarcello L, Lyon S, Rosati FC, et al. The puzzle of "idle" children: neither in school nor performing economic activity: evidence from six countries. Understanding Children's Work Project draft working paper. 2003.

Bilham R. Lessons from the Haiti earthquake. Nature. 2010;463(7283):878-9.

Birkmann J. Measuring vulnerability to natural hazards: towards disaster resilient societies, Second edition. New York: United Nations University Press; 2013.

Blaikie P, Cannon T, Davis I, Wisner B. At Risk II: natural hazards, people's vulnerability and disasters. London and New York: Routledge; 2014.

Booysen F, Van Der Berg S, Burger R, Von Maltitz M, Du Rand G. Using an asset index to assess trends in poverty in seven Sub-Saharan African countries. World Dev. 2008;36(6):1113-30.

Borensztein E, Cavallo E, Valenzuela P. Debt sustainability under catastrophic risk: the case for government budget insurance. Risk Manag Insur Rev. 2009;12(2):273-94.

Briguglio L. Small island developing states and their economic vulnerabilities. World Dev. 1995;23(9):1615-32.

Brown R, Kulik J. Flashbulb memories. Cognition. 1977;5(1):73-99.

Buchmann C. Family structure, parental perceptions, and child labor in Kenya: what factors determine who is enrolled in school? Soc Forces. 2000;78(4):1349-78.

Bustelo M, Arends-Kuenning MP, Lucchetti L. Persistent impact of natural disasters on child nutrition and schooling: evidence from the 1999 Colombian earthquake. IZA Discussion Paper IZA No. 6354. 2012.

Cavallo E, Noy I. The economics of natural disasters: a survey. IDB Working Paper No. 124. 2009.

Cavallo E, Powell A, Becerra O. Estimating the direct economic damages of the earthquake in Haiti. Econ J. 2010;120(546):298-312.

Cigno A, Rosati FC. The economics of child labour. ILR Rev. 2006;60(2):86.

Dammert AC. Siblings, child labor, and schooling in Nicaragua and Guatemala. J Population Econ. 2010;23(1):199-224.

Dayton-Johnson J. Natural disasters and adaptive capacity. OECD Development Centre Working Papers No. 247: OECD Publishing; 2004.

De Janvry A, Finan F, Sadoulet E, Vakis R. Can conditional cash transfer programs serve as safety nets in keeping children at school and from working when exposed to shocks? J Dev Econ. 2006;79(2):349-73.

De Nicola F, Giné X. How accurate are recall data? Evidence from coastal India. J Dev Econ. 2014;106:52-65.

De Vreyer P, Gubert F, Rakoto Tiana N. The work-school trade-off among children in West Africa: are household tasks more compatible with school than economic activities? In: De Vreyer P, Roubaud F, editors. Urban labor markets in sub-Saharan Africa, Africa Development Forum Series, Banque Mondiale. Washington: Banque Mondiale; 2013. p. 349-72. http://www.documentation.ird.fr/hor/fdi:010063792.

Delap E. Economic and cultural forces in the child labour debate: evidence from urban Bangladesh. J Dev Stud. 2001;37(4):1-22.

Dex S. The reliability of recall data: a literature review. Bull Methodologie Sociologique. 1995;49(1):58-89.

Doocy S, Daniels A, Packer C, Dick A, Kirsch TD. The human impact of earthquakes: a historical review of events 1980-2009 and systematic literature review. PLoS Curr Disasters. 2013. Edition 1. doi:10.1371/currents.dis.67bd14fe457f1db0b5433a8ee20fb833.

Doocy S, Jacquet G, Cherewick M, Kirsch TD. Haiti earthquake: a stratified cluster survey. Injury. 2013;44(6):842-7.

Eberhard MO, Baldridge S, Marshall J, Mooney W, Rix GJ. The mw 7.0 Haiti earthquake of January 12, 2010: USGS/EERI advance reconnaissance team report. Technical report, USGS. 2010.

Échevin D. Vulnerability and livelihoods before and after the Haiti earthquake. World Bank Policy Research Working Paper Series No. 5850. 2011.

Edmonds EV. Understanding sibling differences in child labor. J Population Econ. 2006;19(4):795-821.

Edmonds, EV. Child labor. Handb Dev Econ. 2007;4:3607-9.

EM-DAT. Emergency Events Database. Institution: The OFDA/CRED International Disaster Database. 2015. Available at http://www.emdat.be/. Accessed 4 Mar 2015.

Fan CS. Relative wage, child labor, and human capital. Oxford Econ Papers. 2004;56(4):687-700.

Field CB. Managing the risks of extreme events and disasters to advance climate change adaptation: special report of the intergovernmental panel on climate change. Technical report. 2012.

Grimm M. Does household income matter for children's schooling? Evidence for rural Sub-Saharan Africa. Econ Educ Rev. 2011;30(4):740-54.

Grislain-Letrémy C. Natural disasters: exposure and underinsurance: Working paper g 2013/12, INSEE, CREST, and Paris-Dauphine University; 2013.

GTEF. Vers la refondation du système educatif haïtien. Plan opérationnel 2010-2015, Draft des recommandations du groupe de travail sur léducation et la formation. Technical report, Ministère de l'Education Nationale et de la Formation professionnelle (MENFP). 2011.

Halliday T. Migration, risk, and liquidity constraints in El Salvador. Econ Dev Cult Chang. 2006;54(4):893-925.

Hamilton WD. The genetical evolution of social behaviour. I. J Theor Biol. 1964;7(1):1-16.

Heger M, Julca A, Paddison O. Analysing the impact of natural hazards in small economies: the Caribbean case: Research Paper, UNU-WIDER, United Nations University UNU; 2008.

Herrera J, Lamaute-Brisson N, Milbin D, Roubaud F, Saint-Macary C, Torelli C, Zanuso C. L'évolution des conditions de vie en Haïti entre 2007 et 2012: La réplique sociale du séisme, Technical report, IHSI, IRD, DIAL; 2014.

Huisman J, Smits J. Effects of household- and district-level factors on primary school enrollment in 30 developing countries. World Dev. 2009;37(1):179-93.

Jacoby HG, Skoufias E. Risk, financial markets, and human capital in a developing country. Rev Econ Stud. 1997;64(3): 311-35. 
Jalan J, Ravallion M. Are the poor less well insured? Evidence on vulnerability to income risk in rural China. J Dev Econ. 1999;58(1):61-81.

Jensen P, Nielsen HS. Child labour or school attendance? Evidence from Zambia. J Popul Econ. 1997;10(4):407-24. Jensen R. Agricultural volatility and investments in children. Am Econ Rev. 2000;90:399-404.

Kahn ME. The death toll from natural disasters: the role of income, geography, and institutions. Rev Econ Stat. 2005;87(2): 271-84.

Kolbe AR, Hutson RA, Shannon H, Trzcinski E, Miles B, Levitz N, Puccio M, James L, Noel JR, Muggah R. Mortality, crime and access to basic needs before and after the Haiti earthquake: a random survey of Port-au-Prince households. Med Confl Surviv. 2010;26(4):281-97.

Lamaute-Brisson N. Systèmes de protection sociale en Amérique Latine et dans les Caraïbes: Haïti: Document de travail CEPALC. 2013.

Lamaute-Brisson, N. Promotion et protection sociale de l'enfance et de l'adolescence en Haïti, Série Politiques Sociales, No. 212. 2015.

Levy, V. Cropping pattern, mechanization, child labor, and fertility behavior in a farming economy: Rural Egypt. Econ Dev Cult Change. 1985;777-91.

Lundahl M. The political economy of disaster. Destitution, plunder and earthquake in Haiti. London: Routledge; 2013.

Lunde H. Haiti Youth Survey 2009. Volume II: analytical report. Technical report, FAFO. 2010.

Noy I. The macroeconomic consequences of disasters. J Dev Econ. 2009;88(2):221-31.

Patrinos HA, Psacharopoulos G. Family size, schooling and child labor in Peru—an empirical analysis. J Popul Econ. 1997;10(4):387-405.

Ranjan P. Credit constraints and the phenomenon of child labor. J Dev Econ. 2001;64(1):81-102.

Rasmussen MTN. Macroeconomic implications of natural disasters in the Caribbean. Washington: International Monetary Fund. 2004. pp. 4-224.

Razafindrakoto M, Roubaud F, Torelli C. Measuring the informal sector and informal employment: the experience drawn from 1-2-3 surveys in African countries. African Stat J. 2009;9:88-147.

Saint-Macary C, Zanuso C. Build back better? Long-lasting impact of the 2010 earthquake in Haiti. Working Paper 2015-15, DIAL. 2015.

Salmi J. Equity and quality in private education: the Haitian paradox. Compare. 2000;30(2):163-78.

Santos I. Disentangling the effects of natural disasters on children: 2001 earthquakes in El Salvador. Doctoral Dissertation, Kennedy School of Government, Harvard University. 2007.

Schuller M, Morales P. Tectonic shifts: Haiti since the earthquake. Virginia: Kumarian Press; 2012.

Schwartz T, Pierre Y-F, Calpas É. Building assessments and rubble removal in quake-affected neighborhoods in Haiti. BARR Survey Final Report. 2011.

Senne J-N. Death and schooling decisions over the short and long run in rural Madagascar. J Popul Econ. 2014;27(2): 497-528.

Skoufias E. Economic crises and natural disasters: coping strategies and policy implications. World Dev. 2003;31(7): 1087-102.

Strauss J, Thomas D. Health over the life course. Handb Dev Econ. 2007;4:3375-474.

Strobl E. The economic growth impact of natural disasters in developing countries: evidence from hurricane strikes in the Central American and Caribbean regions. J Dev Econ. 2012;97(1):130-41.

Torche F. The effect of maternal stress on birth outcomes: exploiting a natural experiment. Demography. 2011;48(4): 1473-91.

Webbink E, Smits J, de Jong E. Household and context determinants of child labor in 221 districts of 18 developing countries. Soc Indic Res. 2013;110(2):819-36.

Winograd E, Neisser U. Affect and Accuracy in Recall: Studies of 'Flashbulb' Memories, Vol. 4. New York: Cambridge University Press; 2006.

Yang D. Risk, migration, and rural financial markets: evidence from earthquakes in El Salvador. Soc Res Int Q. 2008;75(3): 955-92.

Zanuso C, Torelli C, Roubaud F. Le marché du travail en Haïti après le séisme: Quelle place pour les jeunes? Autrepart. 2014;71:135-56.

\section{Submit your manuscript to a SpringerOpen ${ }^{\circ}$ journal and benefit from:}

- Convenient online submission

- Rigorous peer review

Open access: articles freely available online

- High visibility within the field

- Retaining the copyright to your article

Submit your next manuscript at $\gg$ springeropen.com 